\title{
THE
}

\section{HUMAN HARVEST}

DAVID STARR JORDAN
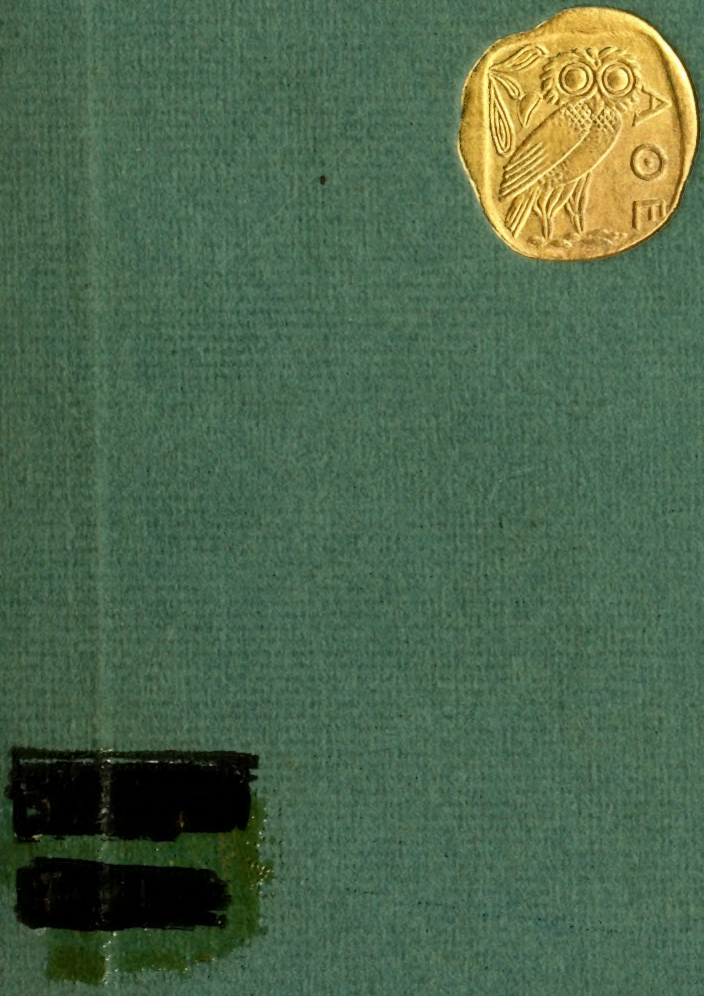



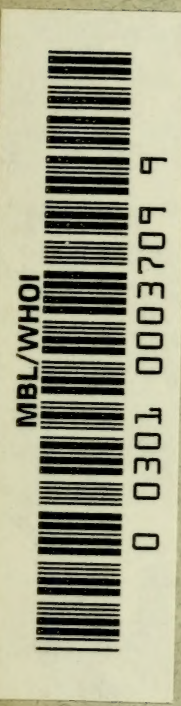







\section{THE}

\section{HUMAN HARVEST}

A STUDY OF THE DECAY OF RACES THROUGH THE SURVIVAL OF THE UNFIT

\section{BY \\ DAVID STARR JORDAN \\ Chancellor of \\ Leland Stanford Junior University}

"La guerre a produit de tout temps une selection à rebours." (Novicow)

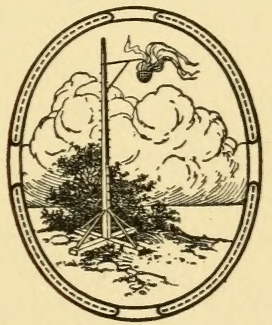

B O S T O N

THE BEACON PRESS

25 BEACON STREET 
Copyright, 1907

The Beacon Press, Inc.

$$
11246
$$


TO THE

MEMORY OF MY BROTHER

\section{RUFUS BACON JORDAN}

$$
\text { (1 } 838-1862)
$$

OF THE

"HUMAN HARVEST"

OF 1862 



\section{PREFATORY NOTE}

$\prod$ HIS little book contains the substance 1 of two essays on the same subject, the one originallydelivered in Stan fordUniversity in 1899, and reprinted by the American Unitarian Association with the title of "The Blood of the Nation," the other read at Philadelphia in I906, at the two hundredth anniversary of the birth of Benjamin Franklin, with the title, "The Human Harvest." This was printed in the Proceedings of the American Philosophical Society.

D. s. J.

Stanford University, California 


\section{$\mathrm{H}^{\mathrm{OW}}$ long will the Republic endure? So}

1 long as the ideas of its founders remain dominant. How long will these ideas remain dominant? Fust solong as the blood of its founders remains dominant in the blood of its people. Not the blood of Puritans andVirginians alone, the original creators of free states, but the blood of free-born men, be they Greek, Roman, Frank, Saxon, Norman, Dane, Celt, Scot, Goth or Samurai. It is a free stock that creates a free nation. Our Republic shall endure so long as the human harvest is good, so long as the movement of history, the progress of science and industry, leaves for the future the best and not the worst of each generation. 


\section{TABLE OF CONTENTS}

The Human Harvest

PAGE

A Dream of Fair Horses

A Dream of Swift Horses

The Story of the Vires

Reversal of Selection in Rome

Rise of the Mob in Rome

Words of Franklin

Words of Otto Seeck

The Fall of Rome

28

$V$ ir and Homo

History Repeats Itself

The Field of Novara

35

A French Cartoon

36

Blood determines History

38

History determines Blood

39

Men and Beasts under the same Laws

Selective Breeding

Meaning of Progress

Illustrations from France

Heredity repeats what she finds

The Man of the Hoe

The Sifting of Men in France

The Nobles and the Peasantry

Effects of Primogeniture 
Reversed Selection in the Reign of Terror 58 The Cbronicle of the Drum

Reversed Selection tbrough Repression and

Intolerance

60

Reversed Selection tbrough Monasticism 6I Reversed Selection through Abuse of

Charity

Saved from the Army

Alcoholism in Race-Selection

Reversed Selection through the Rush to

\section{Cities}

Reversed Selection tbrough $W$ ar

Wiertz's Painting of Napoleon

Napoleon's Campaigns

The Fall of Greece

The Case of Germany

Effects of Emigration

What does be know of England, who only

England knows?

80

The Case of Switzerland

80

The Case of Spain

82

The Greatness of Japan

83

What of England?

85

"There's a Widow in Sleepy Chester" 86

Testimony of Kipling 
The Revelry of the Dying

The Band in the Pine-Wood

90

Contents

The Song of the Dead

9 I

Ave Imperatrix

92

Tommy Atkins

93

99

The Survival of the Fittest in War? IOI

$W$ bat of America?

102

Significance of "Sons of the Revolution" $\mathrm{IO}_{3}$

$W$ ar sometimes inevitable

Brownell's Roll of Honor IO4

The Pbantom Army

106

How long will the Republic endure?

I I 2

Like the Seed is the Harvest

I I 5

$W$ ar as a Source of National Strength

I 16

$W$ ar one Infuence among Many

I 7

Advantages of Civil $W$ ar

I I 8

The best Political Economy

I 20

I 2 I 

THE HUMAN HARVEST 

THE HUMAN HARVEST WAS BAD!"

Thus the historian sums up the

1 conditions in Rome in the days of the good emperor Marcus Aurelius.

By this he meant that while population and wealth were increasing, manhood had failed. There were men enough in the streets of Rome, men enough in the camps, men enough in the menial labor or in no labor at all, but of good soldiers there were too few. "Vir had given place to homo," Roman men to mere human beings. For the business of the state, which in those days was mainly war, the men were inadequate.

In the recognition of this condition we touch the overshadowing fact in the history of Europe, the effect of military selection on the breed of men. This lesson, in such fashion as I may, I shall try to set forth in these pages.

In beginning this discussion I must bring forward certain fragments of history, stories told because they are true, and one parable not true, but told for the lesson it teaches. And this is the first: Once there was a man, strong, wealthy and patient, who dreamed

A Dream

of fair

Horses

[ 13$]$ 
The of a finer type of horse than had ever yet Human Harvest existed. This horse should be handsome, clean-limbed, intelligent, docile, strong and swift. These traits were to be not those of one horse alone, a member of a favored equine aristocracy, they were to be "bred in the bone" so that they would continue from generation to generation the attributes of a special common type of horse. And with this dream ever before his waking eyes, he invoked for his aid the four twin genii of organic life, the four by which all the magic of transformism of species has been accomplished either in nature or in art. And these forces once in his service, he left to their control all the plans included in his great ambition. These four genii or fates are not strangers to us, nor were they new to the human race. Being so great and so strong, they are invisible to all save those who seek them. Men who deal with them after the fashion of science give them commonplace names, - variation, heredity, segregation, selection.

Because not all horses are alike, because in fact no two were ever quite the same, the 
first appeal was made to the genius of Variation. Looking over the world of horses, he found to his hand Kentucky race-horses, clean-limbed, handsome and fleet, some more so and others less. So those which had the most of the virtues of the horse which was to be were chosen to be blended in new creation. Then again, he found English thoroughbred horses, selected stock of Arabian ancestry, hardy and strong and intelligent. These virtues were needed in the production of the perfect horse. And here came the need of the second genius, who is called Heredity. With the crossing of the racer with the thoroughbred, all qualities of both were blended in the progeny. The next generation partook of all desirable traits and again of undesirable ones as well, some the one, and some the other, for sire and dam alike had given the stamp of its own kind and for the most part in equal degree. But again never in a degree quite equal, and in some measure these matters varied with each sire and each dam, and with each colt of all their progeny. It was found that the progeny of the mare called Beautiful Bells ex-

The

Human

Harvest 
The

Human

Harvest

celled all others in retaining all that was good in fine horses, and in rejecting all that a noble horse should not have. And like virtues were attached to the sires called Palo Alto, Electricity and Electioneer.

But there were horses and horses; horses not of the chosen breed, and should these enter the fold with their common blood it would endanger all that had been already accomplished. For the ideal horse mating with the common horse controls at the best but half the traits of the progeny. If the strain were to be established, the vulgar horseflesh must be kept away, and only the best remain in association with the best. Thus Segregation, the third of the genii, was called into service lest the successes of this herd be lost in the failure of some other.

Under the spell of Heredity all the horses partook of the charm of Beautiful Bells and of Electricity and of Palo Alto, for firmly and persistently all others were banished from their presence. There were some who were not strong, some who were not sleek, some who were not fleet, some who were not clean-limbed, nor docile, nor intelligent. 
At least they were not so to the degree which the dream of fair horses demanded. By the force of Selection, all such were sent away. Variation was always at work making one colt unlike another; Heredity made each colt a blend or mosaic of traits of sire and of grandsires and granddams; Selection left only good traits to form this mosaic, and the grandsire and granddam, sire and dam, and the rest of the ancestry lived their lives again in the expanding circle of descent.

Thus, in the final result, the horses who were left were the horses of their owner's dream. The future of the breed was fixed, and fixed at the beginning by the very framing of the conditions under which it lived. It is variation which gives better as well as worse. It is heredity which saves all that has been attained - for better or for worse. It is selection by which better triumphs over worse, and itis segregation which protects the final result from falling again in to the grasp of the general average. In all this, selection is the vital, moving, changing force. It throws the shaping of the future on the individual chosen by the present. The horse

The

Human

Harvest 
The

Human

Harvest

who is left marks the future of his kind. The history of the steed is an elongation of the history of those who are chosen for parentage. And with the best of the best chosen for parentage, the best of the best appears in the progeny. The horse-harvest is good in each generation. As the seed we sow, so shall we reap.

And this story is true, known to thousands of men. And it will be true again just as often as men may try to carry it into experiment. And it will be true not of horses alone, for the four fates which guide and guard life have no partiality for horses, but work just as persistently for cattle or sheep, or plums or roses, or calla or cactus, as they do for horses or for men. From the very beginning of life they have wrought untiringly - and in your life and in mine - in the grass of the field, the trees of the forestin bird and beast, everywhere we find the traces of their energy.

And this brings me to my second story, which is not true as history, but only in its way as parable, forever trying to become true. 
There was once a man-strenuous no doubt, but not wise, for he did not give heed to the real nature of things, and so he set himself to do by his own unaided hand the work which only the genii can accomplish. And this man possessed also a stud of horses. They were docile, clean-limbed, fleet, and strong, and he would make them still more strong and fleet. So he rode them swiftly with all his might, day and night, always on the course, always pushed to the utmost, leaving only the dull and sluggish to remain in the stalls. For it was his dream to fill these horses with the spirit of action, with the glory of swift motion, that this glory might be carried on and on to the last generation of horses. There were some who could not keep the pace, and to these and these alone he assigned the burden of bearing colts. And the feeble and the broken, the dull of wit, the coarse of $\lim b$, became each year the mothers of the colts. The horses who were chosen for the race-course he trained with every care, and every stroke of discipline showed itself in the flashing eyes and straining muscles, - such were the best

The

Human

Harvest

A Dream of swift horses 
The

Human

Harvest

horses. But the other horses were the horses who were left. From their loins came the next generation, and with these there was less fire and less speed than the first horses possessed in such large measure. But still the rush went on - whip and spur made good the lack of native movement. The racers still pushed on the course, while in the stalls and paddocks at home the dull and common horses bore their dull and common colts. Variation was still at work with these as patiently as ever. Heredity followed, repeating faithfully whatever was left to her. Segregation, always conservative, guarded her own, but could not make good the deficiencies. Selection, forced to act perversely, chose for the future the worst and not the best, as was her usual fashion. So the current of life ran steadily downward. The herd was degenerating because it was each year an inferior herd which bred. Each generation yielded weaker colts, rougher, duller, clumsier colts, and no amount of training or lash or whip or spur made any permanent difference for the better. The horseharvest was bad. Thoroughbred and race- 
horse gave place to common beasts, for in the removal of the noble the ignoble always finds its opportunity. It is always the horse that remains which determines the future of the stud.

In like fashion from the man who is left flows the current of human history.

This tale then is a parable, a story of what never was, but which is always trying to become true.

Once there was a great king - and the nation over which he bore rule lay on the flanks of a mountain range, spreading across fair hills and valleys green and fertile across to the Mediterranean Sea. And the men of his race, fair and strong, self-reliant and selfconfident, men of courage and men of action, were men "who knew no want they could not fill for themselves." They knew none on whom they looked down, and none to whom they regarded themselves inferior. And for all things which men could accomplish these plowmen of the Tiber and the Apennines felt themselves fully competent and adequate. Vir, they called themselves in their own tongue, and virile, virilis, men

The

Human

Harvest

The Story of the Vires 
The

Human

Harvest

like them are called to this day. It was the weakling and the slave who was crowded to the wall; the man of courage begat descendants. In each generation and from generation to generation the human harvest was good. And the great wise king who ruled them; but here my story halts - for there was no king. There could be none. For it was written, men fit to be called men, men who are vires, "are too self-willed, too independent, and too self-centred to be ruled by anybody but themselves." Kings are for weaklings, not for men. Men free-born control their own destinies. "The fault is not in our stars, but in ourselves that we are underlings." For it was later said of these same days: "There was a Brutus once, who would have brooked the Eternal Devil to take his seat in Rome, as easily as a king." And so there was no king to cherish and control these men his subjects. The spirit of freedom was the only ruler they knew, and this spirit being herself metaphoric, called to her aid the four great genii which create and recreate nations. Variation was ever at work, while heredity held fast all that she 
developed. Segregation in her mountain fastnesses held the world away, and selection chose the best and for the best purposes, casting aside the weakling and the slave, holding the man for the man's work; and ever the man's work was at home, building the cities, subduing the forests, draining the marshes, adjusting the customs and statutes, preparing for the new generations. So the men begat sons of men after their own fashion, and the men of strength and courage were ever dominant. The Spirit of Freedom was a wise master, cares wisely for all that he controls.

So in the early days, when Romans were men, when Rome was small, without glory, without riches, without colonies and without slaves, these were the days of Roman greatness.

Then the Spirit of Freedom little by little gave way to the Spirit of Domination. Conscious of power, men sought to exercise it, not on themselves but on one another. Little by little this meant banding together, aggression, suppression, plunder, struggle, glory, and all that goes with the pomp and

The

Human

Harvest 
Reversal of selection in Rome
The Human Harvest

circumstance of war. The individuality of men was lost in the aggrandizement of the few. Independence was swallowed up in ambition, patriotism came to have a new meaning. It was transferred from the hearth and home to the trail of the army.

It does not matter to us now what were the details of the subsequent history of Rome. We have now to consider only a single factor. In science this factor is known as "reversal of selection." "Send forth the best ye breed!" That was the word of the Roman war-call. And the spirit of Domination took these words literally, and the best were sent forth. In the conquests of Rome, Vir, the real man, went forth to battle and to the work of foreign invasion; Homo, the human being, remained in the farm and the workshop and begat the new generations. Thus "Vir gave place to Homo." The sons of real men gave place to the sons of scullions, stable-boys, slaves, camp-followers, and the riff-raff of those the great, victorious army cannot use but does not exclude.

$$
\text { The fall of Rome was not due to luxury, }
$$


effeminacy, corruption, the wickedness of Nero and Caligula, the weakness of the train of Constantine's worthless descendants. It was fixed at Philippi, when the spirit of domination was victorious over the spirit of freedom. It was fixed still earlier, in the rise of consuls and triumvirates and the fall of the simple, sturdy, self-sufficient race who would brook no arbitrary ruler. When the real men fell in war, or were left in far-away colonies, the life of Rome still went on. But it was a different type of Roman which continued it, and this new type repeated in Roman history its weakling parentage.

Thus we read in Roman history the rise of the mob and of the emperor who is the mob's exponent. It is not the presence of the emperor which makes imperialism. It is the absence of the people, the want of men. Babies in their day have been emperors. A wooden image would serve the same purpose. More than once it has served it. The decline of a people can have but one cause, the decline in the type from which it draws its sires. A herd of cattle can degenerate in no other way than this, and a race of men 
The Human Harvest

is under the same laws. By the rise in absolute power, as a sort of historical barometer, we may mark the decline in the breed of the people. We see this in the history of Rome. The conditional power of Julius Cæsar, resting on his own tremendous personality, showed that the days were past of Cincinnatus and of Junius Brutus. The power of Augustus showed the same. But the decline went on. It is written that "the little finger of Constantine was thicker than the loins of Augustus." The emperor in the time of Claudius and Caligula was not the strong man who held in check all lesser men and organizations. He was the creature of the mob; and the mob, intoxicated with its own work, worshipped him as divine. Doubtless the last emperor, Augustulus Romulus, before he was thrown into the scrap-heap of history, was regarded in the mob's eyes and his own as the most superhuman of them all.

What have the historians to say of these matters? Very few have grasped the full significance of their own words, for very few [26] have looked on men as organisms, and on 
nations as dependent on the specific character of the organisms destined for their reproduction.

So far as the writer knows, the first one to think of man thus as "an inhabitant," a species in nature among other species and dependent on nature's forces as other animals and other inhabitants must be, was Benjamin Franklin.

"All war is bad," said he, "some wars worse than others." Then, once again, in more explicit terms, referring to the dark shadow of war cast over scenes of peace, the evil of the standing army, Franklin said to Baynes :

"If one power singly were to reduce its standing army it would be instantly overrun by other nations. Yet I think there is one effect of a standing army which must in time be felt so as to bring about the abolition of the system. A standing army not only diminishes the population of a country, but even the size and breed of the human species. For an army is the flower of the nation. All the most vigorous, stout, and well-made men in a kingdom are to be

The

Human

Harvest

Words of

Franklin 
The found in the army, and these men in genHuman Harvest

Vierws of

Otto Seeck eral cannot marry."1

What is true of standing armies is far more true of armies that fight and fall; for, as Franklin said again, "Wars are not paid for in war times: the bill comes later." For " in all times," as Novicow observes, "war must reverse the process of selection." " Similar observations as to the effects of military selection are recorded by Herbert Spencer.

In his great history of "The Downfall of the Ancient World" (Der Untergang der antiken Welt), Professor Otto Seeck, of the University of Greifeswald, finds this downfall due solely to the rooting out of the best ("die Ausrottung der Besten"). The historian of the "Decline and Fall of the Roman Empire," or any other empire, is engaged solely with the details of the process by which the best men are exterminated. Speaking of Greece, Dr. Seeck says, "A wealth of force of spirit went down in the

'Parton's “ Life of Franklin," II, p. 572.

${ }^{2} \mathrm{La}$ guerre a produit de tout temps une selection à rebours" (Novicow). 
suicidal wars." "In Rome, Marius and Cinna slew the aristocrats by hundreds and thousands. Sulla destroyed the democrats, and not less thoroughly. Whatever of strong blood survived, fell as an offering to the proscription of the Triumvirate." "The Romans had less of spontaneous force to lose than the Greeks. Thus desolation came to them sooner. Whoever was bold enough to rise politically in Rome was almost without exception thrown to the ground. Only cowards remained, and from their brood came forward the new generations. Cowardice showed itself in lack of originality and in slavish following of masters and traditions." The Romans of the Republic could not have made the history of the Roman Empire. In their hands it would have been still a republic. Could they have held aloof from world-conquering schemes, Rome might have remained a republic, enduring even to ourown day. The seeds of destruction lie not in the race nor in the form of government, nor in ambition, nor in wealth, nor in luxury, but in the influences by which the best men are cut off from the work of parenthood.

The fall of Rome 
The

Human Harvest

"The Roman Empire," says Seeley, "perished for want of men." Even Julius Cæsar notes the dire scarcity of men ( $\delta \epsilon \iota \nu \eta^{\prime} \nu$ ỏ $\lambda_{\iota}$ -

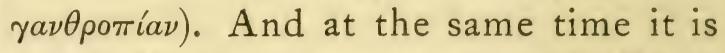
noted that there are men enough. Rome was filling up like an overflowing marsh. Men of a certain type were plenty, " people with guano in their composition," to use Emerson's striking phrase, but the selfreliant farmers, "the hardy dwellers on the flanks of the Apennines," the Roman men of the early Roman days, these were fast going, and with the change in the breed came the change in Roman history.

" The mainspring of the Roman army for centuries had been the patient strength and courage, capacity for enduring hardships, instinctive submission to military discipline of the population that lined the Apennines."

With the Antonines came "a period of sterility and barrenness in human beings." "The human barvest was bad." Bounties were offered for marriage. Penalties were devised against race-suicide. "Marriage," says Metellus, "is a duty which, however painful, every citizen ought manfully to dis- 
charge." Wars were conducted in the face of a declining birth-rate, and this decline in quality and quantity of the human harvest engaged very early the attention of the wise men of Rome.

"The effect of the wars was that the ranks of the small farmers were decimated, while the number of slaves who did not serve in the army multiplied" (Bury).

Thus "Vir gave place to Homo," real men to mere human beings. There were always men enough such as they were. "A hencoop will be filled, whatever the (original) number of hens," said Benjamin Franklin. And thus the mob filled Rome. No wonder the mob-leader, the mob-hero rose in relative importance. No wonder that "the little finger of Constantine was thicker than the loins of Augustus." Nowonder that "if Tiberius chastised his subjects with whips, Valentinian chastised them with scorpions."

"Government having assumed godhead, took at the same time the appurtenances of it. Officials multiplied. Subjects lost their rights. Abject fear paralyzed the people and those that ruled were intoxicated with

The

Human

Harvest

Vir and Homo 
insolence and cruelty" (Zumpt). "The worst government is that which is most worshipped as divine." "The emperor possessed in the army an overwhelming force over which citizens had no influence, which was totally deaf to reason or eloquence, which had no patriotism because it had no country, which had no humanity because it had no domestic ties." "'There runs through Roman literature a brigand's and barbarian's contempt for honest industry." " Roman civilization was not a creative kind, it was military, that is, destructive." What was the end of it all? The nation bred real men no more. To cultivate the Roman fields "whole tribes were borrowed." The man of the quick eye and the strong arm gave place to the slave, the scullion, the pariah, the man with the hoe, the man whose lot does not change, because in him there lies no power to change it. "Slaves have wrongs, but freemen alone have rights." So at the end the Roman world yielded to the barbaric, because it was weaker in force. "The barbarian settled and peopled the empire rather than conquered it." It was the 
weakness of war-worn Rome that gave the Germanic races their first opportunity. And the process is recorded in history as the fall of Rome. "

"Out of every hundred thousand strong men, eighty thousand were slain. Out of every bundred thousand weaklings ninety to ninety-five thousand were left to survive." This is Dr. Seeck's calculation, and the biological significance of such mathematics must be evident at once. Dr. Seeck speaks with scorn of the idea that Rome fell from the decay of old age, from the corruption of luxury, from neglect of military tactics or from the over-diffusion of culture.

"It is inconceivable that the mass of Romans suffered from over-culture." ${ }_{2}$ "In condemning the sinful luxury of wealthy Romans, we forget that the trade-lords of the

I "Die Ausrottung der Besten, die jenen schwächeren Volken die Vernichtung brachte, hat die starken Germanen erst befähigt, auf den Trümmern der antiken Welt neue dauernde Gemeinschaften zu errichten." - Otto Seeck.

2 “ Damitsprechend hat man das Wort ‘ Ueberkultur' überhaupt erfunden, als wenn ein zu grosses Maass von Kultur überhaupt denkbar wäre." - O OTro SEecK.

The

Human

Harvest 
The fifteenth and sixteenth centuries were scarceHuman Harvest ly inferior in this regard to Lucullus and Apicius, their waste and luxury not constituting the slightest check to the advance of the nations to which these men belonged. The people who lived in luxury in Rome were scattered more thinly than in any modern state of Europe. The masses lived at all times more poorly and frugally because they could do nothing else. Can we conceive that a war-force of untold millions of people is rendered effeminate by the luxury of a few hundreds?"

"Too long have historians looked on the rich and noble as marking the fate of the world. Half the Roman Empire was made up of rough barbarians untouched by Greek or Roman culture."

"Whatever the remote and ultimate cause may have been, the immediate cause to which the fall of the empire can be traced is a physical, not a moral decay. In valor, discipline and science the Roman armies remained what they had always been, and the peasant emperors of Illyricum were worthy successors of Cincinnatus and Caius Marius. 
But the problem was, how to replenish those armies. Men were wanting. The Empire perished for want of men" (Seeley). To say that nations die of "old age" is the veriest nonsense. Nations fail only when they cease to breed men.

"Severe," "austere" are good old Roman words, and to other emperors besides Septimius Severus they were applied with justice. "Luxurious," "uxorious" are also Roman words, and for some emperors these were used also. But for the most part these were no more characteristic than the others.

Does history ever repeat itself? It always does if it is true history. If it does not we are dealing not with history but with mere succession of incidents. Like causes produce like effects, just as often as man may choose to test them. Whenever men use a nation for the test, poor seed yields a poor fruitage. Where the weakling and the coward survives in human history, there "the human harvest is bad," and it can never be otherwise.

Not long ago I visited the city of Novara, in northern Italy. There, just to the south

The

Human

Harvest

History repeats itself 
The of the town, in a wheat-field, the farmers Human Harvest

The field of Norvara have ploughed up skulls of men till they have piled up a pyramid ten or twelve feet high. Over this pyramid some one has built a canopy to keep off the rain. These were the skulls of young men of Savoy, Sardinia, and Austria, - men of eighteen to thirtyfive years of age, without physical blemish so far as may be, - peasants from the farms and workmen from the shops, who met at Novara to kill each other over a matter in which they had very little concern. Should Charles Albert, the Prince of Savoy, sit on his unstable throne or must he yield it to some one else? This was the question, and this question the battle of Novara tried to decide. It matters not what this decision was. History records it, as she does many matters of less moment. But this fact concerns us, - here in thousands they died. Farther on, Frenchmen, Austrians, and Italians fell together at Magenta, in the same cause. You know the color that we call Magenta, the hue of the blood that flowed out under the olive-trees. Solferino, once that battle-field gave its name to scarlet ribbons, the hue of 
the blood that stained her orange-groves. Lodi, Marengo - all these names call up memories of idle carnage, of wasted life. Go over Italy as you will, there is scarcely a spot not crimsoned by the blood of France, scarcely a railway station without its pile of French skulls. You can trace them across to Egypt, to the foot of the Pyramids. You will find them in Germany, - at Ulm and Wagram, at Jena and Leipzig, at Lützen and Bautzen, at Hohenlinden and at Austerlitz. You will find them in Russia, at Moscow; in Belgium, at Waterloo. "A boy can stop a bullet as well as a man," said Napoleon; and with the rest are the skulls and bones of boys, "ere evening to be trodden like the grass." "Born to be food for powder" was the grim epigram of the day, summing up the life of the French peasant. Read the dreary record of the glory of France, the slaughter at Waterloo, the wretched failure of Moscow, the miserable deeds of Sedan, the waste of Algiers, the poison of Madagascar, the crimes of IndoChina, the hideous results of barrack vice and its entail of disease and sterility, and 
you will understand the " Man of the Hoe." The man who is left, the man whom glory cannot use, becomes the father of the future men of France. As the long-horn aboriginal type reappears in a neglected or abused herd of high-bred cattle, so comes forth the aboriginal man, the "Man of the Hoe," in a wasted race of men.

In the loss of war we count not alone the man who falls or whose life is tainted with disease. There is more than one in the man's life. The bullet that pierces his heart goes to the heart of at least one other. For each soldier has a sweetheart; and if she remain single for his sake, so far as the race is concerned, the one is lost as well as the other. A recent French cartoon pictures the peasant of a hundred years ago ploughing in a field, hopeless and dejected, a gilded marquis on his back, tapping his gilded snuffbox. Another cartoon shows the French peasant of to-day, still at the plough, and equally hopeless. On his back is an armed soldier who should be at another plough, while on the back of the soldier rides the second burden of Shylock the money-lender, 
more cruel and more heavy even than the dainty marquis of the old régime. So long as war remains, the burden of France cannot be shifted.

In the evolution of races and of nations we find at the outset two general laws, the one self-evident, the other not apparent at first sight, but equally demonstrable. The blood of a nation determines its history. This is the first proposition. The second is, The history of a nation determines its blood. As for the first, no one doubts that the character of men controls their deeds. In the long run and with masses of mankind this must be true, however great the emphasis we may lay on individual initiative or on individual variation.

Equally true is it that the present character of a nation is made by its past history. Those who are alive to-day are the resultants of the stream of heredity as modified by the vicissitudes through which the nation has passed. The blood of the nation flows in the veins of those who survive. Those who die without descendants can not color the stream of heredity. It must take its traits from the actual parentage.

The

Human

Harvest

Blood determines history 
The

Human

Harvest

The word "blood" in this sense is figurative only, an expression formed to cover the qualities of heredity. Such traits, as the phrase goes, "run in the blood." In the earlier philosophy it was held that blood was the actual physical vehicle of heredity, that the traits bequeathed from sire to son as the characteristics of families or races ran literally in the literal blood. We know now that this is not the case. We know that the actual blood in the actual veins plays no part in heredity, that the transfusion of blood means no more than the transposition of food, and that the physical basis of the phenomena of inheritance is found in the structure of the germ-cell and its contained germ-plasm.

But the old word well serves our purposes. The blood which is "thicker than water" is the symbol of race unity. In this sense the blood of the people concerned is at once the cause and the result of the deeds recorded in their history. For example, wherever an Englishman goes, he carries with him the elements of English history. It is a British deed which he does, British history that he makes. Thus, too, a Jew is a Jew in all ages 
and climes, and his deeds everywhere bear the stamp of Jewish individuality. A Greek is a Greek; a Chinaman remains a Chinaman. In like fashion the race-traits color all history made by Tartars, or negroes, or Malays, or Japanese.

The climate which surrounds a tribe of men may affect the activities of these men as individuals or as an aggregate, education may intensify their powers or mellow their prejudices, oppression may make them servile or dominion make them overbearing; but these traits and their resultants, so far as science knows, do not "run in the blood," they are not "bred in the bone." Older than climate or training or experience are the traits of heredity, and in the long run it is always "blood which tells."

On the other hand, the deeds of a race of men must in the end determine its blood. Could we with full knowledge sum up the events of the past history of any body of men, we could indicate the kinds of men destroyed in these events. The others would be left to write the history of the future. It is the "man who is left" in the

The

Human

Harvest

History

deter-

mines

blood

[4I] 
The march of history who gives to history its Human future trend. By the "man who is left" we Harvest

Men and beasts under the same laws

[42] mean the man who remains at home to become the father of the family, as distinguished from the man who in one way or another is sacrificed for the nation's weal or woe. If any class of men be destroyed by political or social forces or by the action of institutions, they leave no offspring, and their like will cease to appear.

"Send forth the best ye breed." If we were to accept this advice literally and completely, the nation in time would breed only second-rate men. By the sacrifice of their best, or the emigration of the best, and by such influences alone, have races and nations fallen from first-rate to second-rate or third-rate in the movement of history.

For a race of men or a herd of cattle are governed by the same laws of selection. Those who survive inherit the traits of their own actual ancestry. In the herd of cattle, to destroy the strongest bulls, the fairest cows, the most promising calves, is to allow those not strong nor fair nor promising to become the parents of the coming herd. 
Under this influence the herd will deteriorate, although the individuals of the inferior herd are no worse than their own actual parents. Such a process is called race-degeneration, and it is the only race-degeneration known in the history of cattle or men. The scrawny, lean, infertile herd is the natural offspring of the same type of parents. On the other hand, if we sell or destroy the rough, lean, or feeble calves, we shall have a herd descended from the best. It is said that when the short-horned Durham cattle first attracted attention in England, the long-horns which preceded them, inferior for beef or milk, vanished "as if smitten by a pestilence." The fact was that, being less valuable, their owners chose to destroy them rather than the finer Durhams. Thus the new stock came from the better Durham parentage. If conditions should ever be reversed and the Durhams were chosen for destruction, then the long-horns might again appear, swelling in numbers as if by magic, unless all traces of the breed had in the meantime been annihilated.

In selective breeding with any domesti-

The

Human

Harvest 
The Human Harvest

Selective breeding

cated animal or plant, it is possible, with a little attention, to produce wonderful changes for the better. Almost anything may be accomplished with time and patience. To select for posterity those individuals which best meet our needs or please our fancy, and to destroy those with unfavorable qualities, is the function of artificial selection. Add to this the occasional crossing of unlike forms to promote new and desirable variations, and we have the whole secret of selective breeding. This process Youatt calls the "magician's wand" by which man may summon up and bring into existence any form of animal or plant useful to him or pleasing to his fancy.

Among the greatest triumphs of the applied science of our times is the creation of new plants, of new fruits, and new flowers, by the use of known laws of heredity and variation by the skilful hand of Luther Burbank. There is nothing magical or mysterious in all this. "Like the seed is the harvest." The art lies in choosing the right seed.

In the animal world, permanent progress 
comes mainly through selection, natural or artificial, the survival of the fittest to become the parent of the new generation. In the world of man similar causes produce similar results. The word "progress" is, however, used with a double meaning, including the advance of civilization as well as race improvement. The first of these meanings is entirely distinct from the other. The results of training and education lie outside the scope of the present discussion. By training the force of the individual man is increased. Education gives him access to the accumulated stores of wisdom built up from the experience of ages. The trained man is placed in a class relatively higher than the one to which he would belong on the score of heredity alone. Heredity carries with it possibilities for effectiveness. Training makes these possibilities actual. Civilization has been defined as "the sum total of those agencies and conditions by which a race may advance independently of heredity." But while education and civilization may greatly change the life of individuals, and through them that of the nation,

The

Human

Harvest

Meaning of progress 
The

Human

Harvest

Illustrations from France

these influences are spent on the individual and the social system of which he is a part. So far as science knows, education and training play no part in heredity. The change in the blood which is the essence of raceprogress, as distinguished from progress in civilization, finds its cause in selection only. To apply to nations and races of men the principles we know to be valid in cattlebreeding we may take a concrete example. Let us look for a moment at the alleged decadence of France.

Noblest of Roman provinces was Gallia, the favored land, in which the best of the Romans, the Franks and the Northmen have mingled their blood to produce a nation of men, hopefully leaders in the arts of peace, fatally leaders also in the arts of war.

To-day we are told by Frenchmen that France is a decadent nation. This is a confession of judgment, not an accusation of hostile rivals. It does not mean that the slums of Paris are destructive of human life. That we know elsewhere. Each great city has its great burdens, and these fall hard on 
those at the bottom of the layers of society. There is degradation in all great cities, but the great cities are not the whole of France; they are not even typical of the life of France. It is claimed that the decadence is deepseated, not individual. It is said that the birth-rate is steadily falling; that the average stature of men is lower by two inches at least than it was a century ago; that the physical force is less among the peasants at their homes. Legoyt tells us that "it will take long periods of peace and plenty before France can recover the tall statures mowed down in the wars of the republic and the first empire." What is the cause of all this? Intemperence, vice, misdirected education, bureaucracy, and the rush toward readymade careers? These may be symptoms. They are not causes. They are signs of inherited deficiencies in the people themselves. Edmond Demolins asks in that clever volume of his: "In what constitutes the superiority of the Anglo-Saxon?" Before we answer this let us inquire in what constitutes the inferiority of the Latin races? If we admit this inferiority exists in any de-

The

Human

Harvest 
The gree, and if we answer it in any degree, we Human find in the background the causes of the fall Harvest of Greece, the fall of Rome, the fall of Spain. We find the spirit of domination, the spirit of glory, the spirit of war, the final survival of subserviency, of cowardice and of sterility. The man who is left holds in his grasp the history of the future. The evolution of a race is always selective, never collective. Collective evolution among men or beasts, the movement upward or downward of the whole as a whole, irrespective of training or selection, is never a fact. As Lepouge has said, "It exists in rhetoric, not in truth nor in history."

Demolins finds the answer to his question in the false standards of French life, in defects of training and of civic and personal ideals; but the real cause lies deeper than all this. Low ideals in education are developed by inferior men. The school of "handpainted science," of which Dr. Max Nordau is the ablest exponent, finds France a nation of decadents, - a condition due to the inherited strain of an overwrought civiliza[48] tion. To Nordau the word "degenerate" 
is found adequate to explain all eccentricities of French literature, art, politics, or jurisprudence.

But in fact we have no knowledge of the existence of such a thing as nerve-stress inheritance. In any event, the peasantry of France have not been subjected to it. Their life is hard, no doubt, but not stressful; and they suffer more from nerve-sluggishness than from any form of enforced psychical activity. The kind of degeneration Nordau pictures is not a matter of heredity. When not simply personal eccentricity, it is a phase of personal decay. It finds its causes in bad habits, bad training, bad morals, or in the desire to catch public attention for personal advantage. It has no permanence in the blood of the race. The presence on the Paris boulevards of a mob of crazy painters, maudlin musicians, drunken poets, and sensation-mongers, proves nothing as to race degeneracy. When the fashion changes, they will change also. Already the fad of "strenuous life" is blowing them away. Any man of any race withers in an atmosphere of vice, absinthe, and opium. The presence 
of such an atmosphere may be an effect of race decadence, but it is not a cause of the lowered tone of the nation.

Evil influences may kill the individual, but they cannot tarnish the stream of heredity. The child of each generation is free-born so far as heredity goes, and the sins of the fathers are not visited upon him. If vice strikes deeply enough to wreck the man, it is likely to wreck or kill the child as well, not through heredity, but through lack of nutrition. The child depends on its parents for its early vitality, its constitutional strength, the momentum of its life, if we may use the term. For this a sound parentage demands a sound body. The unsound parentage yields the withered branches, the lineage which speedily comes to the end. But this class of influences, affecting not the germ-plasm, but general vitality, has no relation to hereditary qualities, so far as we know.

In heredity there can be no natural or necessary tendency downward or upward. Nature repeats, and that is all. It is not what parents actually are, - but what they might 
have been, which determines the course of inheritance. From the actual parents actual qualities are received, the traits of the man or woman as they might have been, without regard, so far as we know, to the way in which these qualities have been actually developed.

No race as a whole can be made up of " degenerate sons of noble sires." Where decadence exists, the noble sires have perished, either through evil influences, as in the slums of great cities, or else through the movements of history or the growth of institutions. If a nation sends forth the best it breeds to destruction, the second best will take their vacant places. The weak, the vicious, the unthrifty will propagate, and in default of better will have the land to themselves.

We may now see the true significance of the "Man of the Hoe," as painted by Millet, and as pictured in Edwin Markham's verse. This is the Norman peasant, lowbrowed, heavy-jawed, "the brother of the ox," gazing with lack-lustre eye on the things about him. To a certain extent he is

The

Human

Harvest

The man of the Hoe

[5I] 
The

Human

Harvest

typical of a large portion of the French peasantry. Every one who has travelled in France knows well his kind. If it should be that his kind is increasing, it is because his betters are not. It is not that his back is bent by centuries of toil. He was not born oppressed. Heredity carries over not oppression, but those qualities of mind and heart which invite or which defy oppression. The tyrant harms those only that he can reach. The new generation is free-born, and slips from his hands, unless its traits be of the kind which demand new tyrants. From "the beaten members of the beaten races" we cannot count on breeding free-born men.

Millet's "Man of the Hoe" is not the product of oppression, whatever may be the case of the hoe-man imagined by Markham. $\mathrm{He}$ is primitive, aboriginal. His lineage has always been that of the clown and swineherd. The heavy jaw and slanting forehead can be found in the oldest mounds and tombs of France. The skulls of Engis and Neanderthal were typical men of the hoe, and through the days of the Gauls and Romans the race was not extinct. The "lords 
and masters of the earth " can prove an alibi The when accused of the fashioning of the terrible shape of this primitive man. And men of this shape persist to-day in regions never invaded by our social or political tyranny, and their kind is older than any existing social order.

That he is "chained to the wheel of labor" is the result, not the cause, of his impotence. In dealing with him, therefore, we are far from the "labor problem" of to-day, far from the workman brutalized by premature strain and by unequal competition with machinery, and from all the wrongs of the poor as set forth in the conventional literature of sympathy.

In our discussion of national decadence through reversed selection we turn to France simply as a convenient illustration. Her sins have not been always greater than those of other lands, nor is the penalty more significant. Her case rises to our hand to illustrate a principle which applies to all human history and to all groups of plants and animals as well as to man. Our picture, such as it is, must be painted with a broad

The sifting of men in France Harvest in France 
The

Human

Harvest

The nobles

and the peasantry

$[54]$ brush. We have no space for exceptions and qualifications, and these again when understood would only prove the rule. To weigh statistics is impossible, for the statistics we need have never been collected. The evil effects of "military selection" and allied causes have long been recognized by students of social evolution; but the ideas derived from the application of Darwinism to history have not penetrated our current literature.

The survival of the fittest in the struggle for existence is the primal cause of raceprogress and race-changes. But in the red field of human history the natural process of selection is often reversed. The survival of the unfittest is the primal cause of the downfall of nations. Let us see in what ways this cause has operated in the history of France. First, we may consider the relation of the nobility to the peasantry, - the second to the third estate.

The feudal nobility of each nation of Europe was in the beginning made up of the fair, the brave, and the strong. By their courage and strength their men became the 
rulers of the people, and by the same token they chose the beauty of the realm to be their own.

In the polity of England this superiority was emphasized by the law of primogeniture. On " inequality before the law" British polity has always rested. Men have tried to take a certain few, to feed these on " royal jelly," as the young queen-bee is fed, and thus to raise them to a higher class, distinct from all the workers. To take this leisure class out of the struggle and competition of life, so goes the theory, is to make the firstborn and his kind harmonious and perfect men and women, fit to lead and control the social and political life of the state. In England the eldest son is chosen for this purpose, - a good arrangement, according to Samuel Johnson, "because it insures that there shall be only one fool in the family." For the theory of the leisure class forgets that men are made virile by effort and resistance, and the lord developed by the use of " royal jelly" has rarely been distinguished by perfection of manhood.

The gain of primogeniture came to the na-

The

Human

Harvest 
The tion, though not to the individual. It lies Human Harvest

Effects of primogeniture in the fact that the younger sons and the daughters' sons were forced constantly back into the mass of the people. Among the people at large this stronger blood became the dominantstrain. The Englishmen of to-day are the sons of the old nobility, and in the stress of natural selection they have crowded out the children of the swineherd and the slave. The evil of primogeniture has furnished its own antidote; for primogeniture begat democracy. The younger sons in Cromwell's ranks asked on their battle-flags "Why should the eldest receive all and we nothing?" Richard Rumbold, whom they slew in the Bloody Assizes, "could never believe that Providence had sent into the world a few men already booted and spurred, with countless millions already saddled and bridled for these few to ride." Thus these younger sons became the Roundhead, the Puritan, the Pilgrim. They swelled Cromwell's army, they knelt at Marston Moor, they manned the "Mayflower," and in each generation they have fought for liberty in England and in the United States. Studies 
in genealogy show that all this is literally true. All the old families in New England and Virginia trace their lines back to nobility, and thence to royalty. Almost every Anglo-American has, if he knew it, noble and royal blood in his veins. The Massachusetts farmer, whose fathers came from Devon or Somerset, has as much of the blood of the Plantagenets, of William and of Alfred, as flows in any royal veins in Europe. But his ancestral line passes through the working and fighting younger son, not through him who was first born to the purple. The persistence of the strong shows itself in the prevalence of the leading qualities of her dominant strains of blood, and it is well for England that her gentle blood flows in all her ranks and in all her classes. When we consider with Demolins "what constitutes the superiority of the AngloSaxon,"we shall find his descent from theold nobility, "Saxon and Norman and Dane," not the least of its factors.

On the continent of Europe the law of primogeniture existed in less force, and the results were very distinct. All of noble blood

The

Human

Harvest 
Reversed selection of the Reign of Terror

were continuously noble. All belonged to the leisure class. All were held on the backs of a third estate, men of weaker heredity, beaten lower into the dust by the weight of an ever-increasing body of nobility. The blood of the strong rarely mingled with that of the clown. The noblemen were brought up in indolence and ineffectiveness. The evils of dissipation wasted their individual lives, while casting an ever-increasing burden on the villager and on the "farmer who must pay for all."

Hence in France the burden of taxation led to the Revolution and its Reign of Terror. I need not go over the details of dissipation, intrigue, extortion, and vengeance which brought to sacrifice the "best that the nation could bring." In spite of their lust and cruelty, the victims of the Reign of Terror were literally the best from the standpoint of race development. Their weaknesses were those of training in luxury and irresponsible power. These effects were individual only; and their children were free-born, with the capacity to grow up truly noble if removed from the evil surroundings of the palace. 
In Thackeray's "Chronicle of the Drum," the old drummer, Pierre, sunning himself at the city gate, tells the story of the Reign of Terror :-

The glorious days of September Saw many aristocrats fall;

'Twas then that our pikes drank the blood In the beautiful breast of Lamballe.

Pardi, 'twas a beautiful lady!

I seldom have looked on her like;

And I drummed for a gallant procession

That marched with her head on a pike.

Then they showed her pale face to the Queen, who fell fainting to the floor.

The old drummer goes on with the story of the new ruler of France, "La Mère Guillotine":

Awful, and proud, and erect,

Here sat our republican goddess.

Each morning her table was decked

With dainty aristocrats' bodies.

The people each day flocked around

As she sat at her meat and her wine:

' $T$ was always the use of our nation

To witness the sovereign dine.

The

Human

Harvest

The

Chronicle

of the

Drum 


\section{The Human Harvest}

Reversed selection through repression and intolerance [60]
Young virgins with fair golden tresses,

Old silver-haired prelates and priests, Dukes, marquises, barons, princesses, Were splendidly served at her feasts. Ventrebleu! but we pampered our ogress

With the best that the nation could bring, And dainty she grew in her progress, And called for the head of a king!

Thus the slaughter went on until the man on horseback came, and the mob, "alive but most reluctant," was itself forced into the graves it had dug for others.

And since that day the "best that the nation could bring," those who fell in the Reign of Terror, have been without descendants, - the men less manly than the sons of the Girondins would have been, the women less beautiful than the daughters of Lamballe. The political changes which arose may have been for the better; the change in the blood was all for the worse. Other influences which destroyed the best were social repression, religious intolerance and the intolerance of irreligion and unscience. It was the atheist mob of Paris which destroyed Lavoisier, with the sneer 
that the new republic of reason had no use for savants. The old conservatism burned the heretic at the stake, banished the $\mathrm{Hu}-$ guenot, destroyed the lover of freedom, silenced the agitator. Its intolerance gave Cuvier and Agassiz to Switzerland, sent the Le Contes to America, the Jouberts to Holland, and furnished the backbone of the fierce democracy of the Transvaal. While not all agitators are sane, and not all heretics right-minded, yet no nation can spare from its numbers those men who think for themselves and those who act for themselves. It cannot afford to drive away or destroy those who are filled with religious zeal, nor those whose religious zeal takes a form not approved by tradition nor by consent of the masses. All movements toward social and religious reform are signs of individual initiative and individual force. The country which stamps out individuality will soon live in the mass alone.

A French writer has claimed that the decay of religious spirit in France is connected with the growth of religious orders of which celibacy is a prominent feature. If religious

Reversed selection through monasticism

[6r]

Harvest 
Reversed selection through abuse of charity

Human
Harvest

The men and women leave no descendants, their own spirit, at least, will fail of inheritance. A people careless of religion inherit this trait from equally careless ancestors.

Indiscriminate charity has been a fruitful cause of the survival of the unfit. To kill the strong and feed the weak is to provide for a progeny of weakness. It is a French writer, again, who says that "Charity creates the misery she tries to relieve; she can never relieve half the misery she creates."

Unwise charity is responsible for half the pauperism of the world. That pauperism has become perpetual is due in part to the charity that, in aiding the poor, helps pauperism to mate with pauperism. It is the duty of true charity to remove the causes of weakness and suffering. It is equally her duty to see that weakness and suffering are not needlessly perpetuated.

Startling results may follow from the selective breeding and preservation of paupers. In the valley of Aosta in northern Italy, and in other Alpine regions, is found the form of idiocy known as crétinism. What is the primitive cause of the crétin, and what 
is the causal connection of crétinism with goitre, a disease of the thyroid glands which always accompanies it, I do not know.

It suffices for our purpose to notice that the severe military selection which ruled in Switzerland, Savoy, and Lombardy for many generations took the strongest and healthiest peasants to the wars, and left the idiot and goitrous to carry on the affairs of life at home. To bear a goitre was to be exempt from military service. Thus in some regions the disease has been a local badge of honor. It is said that when iodine lozenges were given to the children of Savoy in the hope of preventing the enlargement and degeneration of the thyroid gland, mothers would take this remedy away from the boys, preferring the goitre to military service.

In the city of Aosta the goitrous crétin has been for centuries an object of charity. There is a special hospice or asylum devoted to his care and propagation. Theidiot has received generous support, while the poor farmer or laborer with brains and no goitre has had the severest of struggles. In the competition of life a premium has thus 
The been placed on imbecility and disease. The Human Harvest crétin has mated with the crétin, the goitre with the goitre, and charity and religion have presided over the union. The result is that idiocy is multiplied and intensified. The crétin of Aosta has been developed as a new type of man. In fair weather the roads about the city are lined with these awful paupers - human beings with less intelligence than the goose, with less decency than the pig. The asylum for crétins in Aosta is a veritable chamber of horrors. The sharp words of Whymper are fully justified:-

"A large proportion of the crétins who will be born in the next generation will undoubtedly be offsprings of crétin parents. It is strange that self-interest does not lead the natives of Aosta to place their crétins under such restrictions as would prevent their illicit intercourse; and it is still more surprising to find the Catholic Church actually legalizing their marriage. There is something horribly grotesque in the idea of solemnizing the union of a brace of idiots, and, since it is well known that the disease is [64] hereditary and develops in successive gen- 
erations, the fact that such marriages are sanctioned is scandalous and infamous." (Whymper: Scrambles among the Alps.)

True charity would give these creatures not less helpful care, but a care which would guarantee that each individual crétin should be the last of his generation.

The causes of goitre are obscure, perhaps depending on poor nutrition or on mineral substances in the water. The disease itself is not hereditary, so far as known; but susceptibility to it certainly is. By taking away for outside service those who are resistant, the heredity of tendency to goitrous swelling is fastened on those who remain.

Like these mothers in Savoy was a mother in Germany. Not long since a friend of the writer, passing through a Franconian forest, found a young man lying senseless by the way. It was a young recruit for the army who had got into some trouble with his comrades. They had beaten him and left him lying with a broken head. Carried to his home, his mother fell on her knees and thanked God, for this injury had saved him from the army.

Saved

from the army

[65] 
The Human Harvest

Alcoholism in

raceselection

The effect of alcoholic drink on race-progress should be considered in this connection. Authorities do not agree as to the final result of alcohol in race-selection. Doubtless, in the long run, the drunkard will be eliminated; and perhaps certain authors are right in regarding this as a gain to the race. On the other hand, there is great force in Dr. Amos G. Warner's remark, that of all caustics gangrene is the most expensive. The people of southern Europe are relatively temperate. They have used wine for centuries, and it is thought by Dr. Archdall Reid and others that the cause of temperance is to be found in this long use of alcoholic beverages. All those with vitiated or uncontrollableappetites have beendestroyed in the long experience with wine, leaving only those with normal tastes and normal ability of resistance. The free use of wine is, therefore, in this view, a cause of final temperance, while intemperance rages only among those races which nave not long known alcohol, and have not become by selection resistant to it. The savage races [66] which have never known alcohol are even 
less resistant, and are soonest destroyed by it.

In all this there must be a certain element The Human Harvest of truth. The view, however, ignores the evil effect on the nervous system of long continued poisoning, even if the poison be only in moderate amounts. The temperate Italian, with his daily semi-saturation may be no more a normal man than the Scotch farmer with his occasional sprees. The nerve disturbance which wine effects is an evil, whether carried to excess in regularity or irregularity. We know too little of its final result on the race to give certainty to our speculations. It is, moreover, true that most excess in the use of alcohol is not due to primitive appetite. It is drink which causes appetite, and not appetite which seeks for drink. In a given number of drunkards but a very few become such through inborn appetite. It is influence of bad example, lack of courage, false idea of manliness, or some defect in character or misfortune in environment which leads to the first steps in drunkenness. The taste once established grows of itself. In earlier times, when the nature 
The of alcohol was unknown and total abstiHuman Harvest nence was undreamed of, it was the strong, the boisterous, the energetic, the apostle of " the strenuous life," who carried all these things to excess. The wassail bowl, the bumper of ale, the flagon of wine,-all these were the attribute of the strong. We cannot say that those who sank in alcoholism thereby illustrated the survival of the fittest. Who can say that, as the Latin races became temperate, they did not also become docile and weak? In other words, considering the influence of alcohol alone, unchecked by an educated conscience, we must admit that it is the strong and vigorous, not the weak and perverted, that are destroyed by it. At the best, we can only say that alcoholic selection is a complex force which makes for temperance - if at all, at a fearful cost of life which, without alcoholic temptation, would be well worth saving. We cannot easily, with Mr. Reid, regard alcohol as an instrument of racepurification, nor believe that the growth of abstinence and prohibition only prepares [68] the race for a future deeper plunge into dis- 
sipation. If France, through wine, has grown temperate, she has grown tame. "New Mirabeaus," Carlyle tells us, "one hears not of; the wild kindred has gone out with this, its greatest." This fact, whatever the cause, is typical of great, strong, turbulent men who led the wild life of Mirabeau because they knew nothing better.

According to Mr. John O. Varian, in the earlier days of Ireland, before the reasons for temperance came to be better understood, it was always the strong and active among the young men who were first destroyed by alcohol. The impulse to lead carried these into the greatest excesses, with the nervous disintegration and personal decay which is the natural result of extreme nerve-stimulation.

The concentration of the energies of France in the one great city of Paris is again a potent agency in the impoverishment of the blood of the rural districts. All great cities are destroyers of life. Scarcely one would hold its own in population or power, were it not for the young men of the farms. In such destruction, Paris has ever taken

Reversed selection through the rush to cities 
The the lead. The education of the middle Human Harvest classes of France is almost exclusively a preparation for public life. To be an official in a great city is an almost universal ideal. This ideal but few attain, and the lives of the rest are largely wasted. Not only the would-be official, but artist, poet, physician, or journalist, seeks his career in Paris. A few may find it. The others, discouraged by hopeless effort or vitiated by corrosion, faint and fall. Every night some few of these cast themselves into the Seine. Every morning they are brought to the morgue behind the old Church of Notre Dame. It is a long procession and a sad one from the provincial village to the strife and pitfalls of the great city, from hopeand joy to absintheand the morgue. With all its pitiful aspects the one which concerns us is the steady drain on the life-blood of the nation, its steady lowering of the average of the parent stock of the future.

Reversed selection through war [70]

But far more potent for evil to the race than all these influences, large and small, is the one great destroyer, - War. War for glory, war for gain, war for dominion, war 
for freedom, its effect is the same, whatever its real or alleged purpose.

In the Wiertz gallery in Brussels is a wonderful painting, dating from the time of Waterloo, called Napoleon in Hell. It represents the great marshal with folded arms and face unmoved descending slowly to the land of the shades. Before him, filling all the background of the picture with every expression of countenance are the men sent before him by the unbridled ambition of Napoleon. Three millions and seventy thousand there were in all — so history tells us, more than half of them Frenchmen. They are not all shown in one picture. They are only hinted at. And behind the millions shown or hinted at are the millions on millions of men who might have been and are not - the huge widening human wedge of the possible descendants of the men who fell in battle. These men of Napoleon's armies were the youth without blemish, "the best that the nation could bring," "l'elite de l'Europe," chosen as "food for powder," "ere evening to be trampled like the grass," in the rush of Napoleon's great battles.

The

Human

Harvest

Wiertz's painting of Napoleon 
The Human Harvest

Napoleon's campaigns

[72]

These men came from the plow, from the workshop, from the school, the best there were - those from eighteen to thirty-five years of age at first, but afterwards the older and the younger. "A boy will stop a bullet as well as a man." "The more vigorous and well born a young man is," says Novicow, " the more normally constituted, the greater his chance to be slain by musket or magazine, the rifled cannon and other similar engines of civilization." Among those destroyed by Napoleon were "the élite of Europe." "Napoleon," says Otto Seeck, " in a series of years seized all the youth of high stature and left them scattered over many battle-fields, so that the French people who followed them are mostly men of smaller stature. More than once in France since Napoleon's time has the military limit been lowered."

I need not tell again the story of Napoleon's campaigns. It began with the first

I “ La Guerre et ses Prétendus Bienfaits," by J. Novicow, Paris. 1894. This little book contains a specially strong arraignment of the theory and practice of war. 
consulate, the justice and helpfulness of the Code Napoléon, the prowess of the brave lieutenant whose military skill and intrepidity had caused him to deserve well of his nation.

The spirit of freedom gave way to the spirit of domination. The path of glory is one which descends easily. Campaign followed campaign, against enemies, against neutrals, against friends. The trail of glory crossed the Alps to Italy and to Egypt, crossed Switzerland to Austria, crossed Germany to Russia. Conscription followed victory, and victory and conscription debased the human species. "The human harvestwas bad." The first consul became the emperor. The servant of the people became the founder of the dynasty. Again conscription after conscription. "Let them die with arms in their hands. Their death is glorious, and it will be avenged. You can always fill the places of soldiers." These were Napoleon's words when Dupont surrendered his army in Spain to save the lives of a doomed battalion.

With all this came more conscription. After the battle of Wagram, we are told, the

The

Human

Harvest 
French began to feel their weakness, the Grand Army was not the army which fought at UIm and Jena. "Raw conscripts raised before their time and hurriedly drafted into the line had impaired its steadiness."

On to Moscow, " "amidst ever-deepening misery they struggled on, until of the six hundred thousand men who had proudly crossed the Niemen for the conquest of Russia, only twenty thousand famished, frost-bitten, unarmed spectres staggered across the bridge of Korno in the middle of December."

"Despite the loss of the most splendidarmy marshalled by man, Napoleon abated no whit of his resolve to dominate Germany and discipline Russia. . . He strained every effort to call the youth of the empire to arms ... and 350,000 conscripts were promised by the Senate. The mighty swirl of the Moscow campaign sucked in I 50,000 lads of under twenty years of age into the devouring vortex." "The peasantry gave up their sons as food for cannon." But "many

I These quotations are from the " History of Napoleon I," by J. H. Rose. 
were appalled at the frightful drain on the nation's strength." "In less than half a year after the loss of half a million men a new army nearly as numerous was marshalled under the imperial eagles. But the majority were young, untrained troops, and it was remarked that the conscripts born in the year of Terror had not the stamina of the earlier levies. Brave they were, superbly brave, and the emperor sought by every means to breathe into them his indomitable spirit." "Truly the emperor could make boys heroes, but he could never repair the losses of I8I2." "Soldiers were wanting, youths were dragged forth." The human harvest was at its very worst. "To fill hell with heroes," - in these words some one has summed up the life-work of the great Napoleon.

And the sequel of it all is the decadence of France. In the presence of war - of war on such a mighty, ruthless and ruinous scale - one does not have to look far to find in what constitutes the superiority of the Anglo-Saxon. And we see the truth in Franklin's words, the deeper truth of their

The

Human

Harvest 
The

Human

Harvest

Fall of Greece

deeper wisdom: "Men do not pay for war in war time; the bill comes later."

Greece died because the men who made her glory had all passed away and left none of their kin and therefore none of their kind. " 'T is Greece, but living Greece no more"; for the Greek of to-day, for the most part, never came from the loins of Leonidas or Miltiades. He is the son of the stableboys and scullions and slaves of the day of her glory, those of whom imperial Greece could make no use in her conquest of Asia. "Most of the old Greek race," says Mr. W. $H$. Ireland, "has been swept away, and the country is now inhabited by persons of Slavonic descent. Indeed, there is strong ground for the statement that there was more of the old heroic blood of Hellas in the turkish army of Edhem Pasha than in the soldiers of King George, who fled before them three years ago." King George himself is only an alien placed on the Grecian throne to suit the convenience of the outside powers, which to the ancient Greeks were merely factions of barbarians. 
Earth, render back from out thy breast

A remnant of thy Spartan dead!

Of the three hundred grant but three

To make a new Thermopylæ!

But there were not even three - not even one - "to make another Marathon," and the Turkish troops swept over the historic country with no other hindrance than the effortless deprecation of Christendom.

In the fall of Greece, as in the fall of Rome, the primal elements we may easily find. The extinction of manly blood, the extinction of freedom of thought and action, increase of wealth gained by plunder, loss of national existence.

So fell Greece and Rome, Carthage and Egypt, the Arabs and the Moors, because, their warriors dying, the nation bred real men no more. The man of the strong arm and the quick eye gave place to the slave, the pariah, the man with the hoe, whose lot changes not with the change of dynasties.

Other nations of Europe may furnish illustrations in greater or less degree. Germany guards her men and reduces the waste

The case of Germany 
Effects of emigration

[78] of war to a minimum. She is "military, but not warlike"; and this distinction means a great deal from the point of view of this discussion. In modern times the greatest loss of Germany has been not from war, but from emigration. If the men who have left Germany are of higher type than those who remain at home, then the blood of the nation is impoverished. That this is the case the Germans in Germany are usually not willing to admit. On the other hand, those competent to judge the GermanAmerican find no type of men in the Old World his mental or physical superior.

The tendency of emigration, whether to cities or to other countries, is to weaken the rural population. An illustration of the results of checking this form of selection is seen in the Bavarian town of Oberammergau. This little village, with a population not exceeding fifteen hundred, has a surprisingly large number of men possessing talent, mental and physical qualities far above the average even in Germany. The cause of this lies in the Passion Play, for which for nearly three centuries Oberam- 
mergau has been noted. The best intellects and the noblest talents that arise in the town find full scope for their exercise in this play. Those who are idle, vicious, or stupid are excluded from it. Thus, in the long run, the operation of selection is to retain those whom the play can use and to exclude all others. To weigh the force of this selected heredity, we have only to compare the quality of Oberammergau with that of other Bavarian towns, as, for example, her sister village of Unterammergau, some two miles lower down, in the same valley.

The effects of emigration run parallel with the effects of war, but with this enormous difference: the strong men who emigrate are not lost to the world. The loss of one region is the gain of another. But the losses in war can yield no corresponding gain.

The effects of emigration can be well studied in England. From Devon and Somerset arose the colony of Massachusetts Bay. From the loins of Old England arose our New England, and from the germ of self-governing New England arose the United States. The counties of Devon and 
The Human Harvest

"What does he know of England who only England knows?"

The case of Switzerland

[80]
Somerset have no importance in the England of to-day comparable with the part they played in the days of Queen Elizabeth. Their influence is over the seas, with the young men who carried with them the names of Plymouth and Dartmouth, of Exeter and Taunton, of Bristol and Bath and Barnstaple.

If we could imagine this New England stock in all its ramifications restored to its old home in Devon and Somerset, what a wonderful storehouse of active life these sleepy old counties would become! From every county of England strong men have gone out to conquer and populate the world. The influence of this greater England on the movement of civilization in our day far exceeds that of the England at home. "What does he know of England who only England knows?"

No stronger line than this was ever written in definition of England's greatness.

Switzerland is the land of freedom, the land of peace. But in earlier times some of the thrifty cantons sent forth their men as hireling soldiers to serve for pay under the 
flag of whomsoever might pay their cost. There was once a proverb in the French court, "Pas d'argent, pas de Suisses" (No money, no Swiss); for the agents of the free republic drove a close bargain.

In Lucerne stands the noblest of all monuments in all the world, the memorial of the Swiss guard of Louis XVI, killed by the mob at the palace of Versailles. It is carved in the solid rock of a vertical cliff above a great spring in the outskirts of the city, a lion of heroic size, a spear thrust through its body, guarding in its dying paws the Bourbon lilies and the shield of France. And the traveller, Carlyle tells us, should visit Lucerne and her monument, "not for Thorwaldsen's sake alone, but for the sake of the German Biederkeit and Tapferkeit, the valor which is worth and truth, be it Saxon, be it Swiss."

Beneath the lion are the names of those whose devotion it commemorates. And with the thought of their courage comes the thought of the pity of it, the waste of brave life in a world that has need for it all. "Sons of the men who knelt at Sempach, but not 
The

Human

Harvest

The case of Spain

$[82]$ to thee, O Burgundy." Switzerland has need of more such sons. It may be fancy, but it seems to me that, as I go about in Switzerland, I can distinguish by the character of the men who remain those cantons who sent forth mercenary troops from those who kept their own for their own upbuilding. Perhaps for other reasons than this Lucerne is weaker than Graubünden, and Unterwaldenlessvirile than little Appenzell. In any event, this is absolutely certain : just in proportion to its extent and thoroughness is military selection a cause of national decline. $^{r}$

Spain died of empire centuries ago. She has never crossed our path. It was only her ghost which walked at Manila and Santiago. In 1630 the Augustinian friar La Puente thus wrote of the fate of Spain: "Against the credit for redeemed souls I set the cost of armadas and the sacrifice of soldiers and friars sent to the Philippines. And this I count the chief loss; for mines give silver,

I ‘ Lors de la guerre de Paraguay la population virile disparut presque complètement, et il ne resta que les malades et les infirmes"' (E. Reclus). 
and forests give timber, but only Spain gives Spaniards, and she may give so many that she may be left desolate, and constrained to bring up strangers' children instead of her own." "This is Castile," said a Spanish knight; "she makes men and wastes them." "This sublime and terrible phrase," says Captain Carlos Gilman Calkins, from whom I have received both these quotations, "sums up Spanish history."

The warlike nation of to-day is the decadent nation of to-morrow. It has ever been so, and in the nature of things it must ever be.

In his charming studies of "Feudal and Modern Japan," Mr. Arthur Knapp, of Yokohama, returns again and again to the great marvel of Japan's military prowess after more than two hundred years of peace. This was shown in the Chinese war. It has been more conclusively shown on the fields of Manchuria since Mr. Knapp's book was written. It is astonishing to him that, after more than six generations in which physical courage has not been demanded, these virile virtues should be found unimpaired.

The

greatness

of Fapan 
The Human Harvest

We can readily see that this is just what we should expect. In times of peace there is no slaughter of the strong, no sacrifice of the courageous. In the peaceful struggle for existence there is a premium placed on these virtues. The virile and the brave survive. The idle, weak, and dissipated go to the wall. "What won the battles on the Yalu, in Korea or Manchuria," says the Japanese, Nitobe, was the ghosts of our fathers guiding our hands and beating in our hearts. They are not dead, these ghosts, those spirits of our warlike ancestors. Scratch a Japanese, even one of the most advanced ideas, and you will find a Samurai." If we translate this from the language of Shintoism to that of science we find it a testimony to the strength of race-heredity, the survival of the ways of the strong in the lives of the selfreliant.

If after two hundred years of incessant battle Japan still remained virile and warlike, that would indeed be the marvel. But that marvel no nation has ever seen. It is doubtless true that warlike traditions are most persistent with nations most frequently 
engaged in war. But the traditions of war and the physical strength to gain victories are very different things. Other things being equal, the nation which has known least of war is the one most likely to develop the "strong battalions" with whom victory must rest.

As Americans we are more deeply interested in the fate of our mother-country than in that of the other nations of Europe.

What shall we say of England and of her relation to the reversed selection of war?

Statistics we have none and no evidence of tangible decline that Englishmen will not indignantly repudiate. When the London press in the vacation season fills its columns with editorials on English degeneration, it is something else to which these journalists refer. Their problem is that of the London slums, of sweat-shops and child-labor, of wasting overwork and of lack of nutrition, of premature old age and of sodden drunkenness, - influences which bring about the degeneration of the individual, the inefficiency of the social group, but which for the most part leave no trace in heredity and are

The

Human

Harvest

What of

England? 
The Human Harvest

There's $a$ widow in sleepy Chester

\section{[86]}

therefore no factor in the degeneration of the race. Such degradation is at once cause, effect and symptom, - a sign of racial inadequacy, a cause of further enfeeblement and an effect of unjust and injurious social, political, and industrial conditions in the past. But with better training the child of the slums rises to normal conditions. Given a fair chance in his youth, and he will show his normal British heritage.

But the problem before us is not the problem of the slums. What mark has been left on England by her great struggles for freedom and by the thousand petty struggles to impose on the world the semblance of order called "Pax Britannica," the British peace?

To one who travels widely through the counties of England some part of the cost is plain.

There's a widow in sleepy Chester Who mourns for her only son;

There's a grave by the Pabeng River, A grave which the Burmans shun.

This is a condition repeated in every village of England, and its history is recorded 
on the walls of every parish church. Everywhere can be seen tablets in memory of young men, - gentlemen's sons from Eton and Rugby and Winchester and Harrow, scholars from Oxford and Cambridge, who have given up their lives in some far-off petty war. Their bodies rest in Zululand, in Cambodia, in the Gold Coast, in the Transvaal. In England only they are remembered. In the parish churches these records are numbered by the score. In the cathedrals they are recorded by the thousand. Go from one cathedral town to another - Canterbury, Winchester, Chichester, Exeter, Salisbury, Wells, Ely, York, Lincoln, Durham, Litchfield, Chester (what a wonderful series of pictures this list of names calls up!), and you will find always the same story, the same sad array of memorials to young men. What would be the effect on England if all of these "unreturning brave" and all that should have been their descendants could be numbered among her sons to-day? Doubtless not all of these were young men of character. Doubtless not all are worthy even of the scant glory of a memorial tablet. But 
The Human Harvest

Testimony of Kipling

most of them were worthy. Most of them were brave and true, and most of them looked out on life with "frank blue British eyes."

This too we may admit, that war is not the only destructive agency in modern society, and that in the struggle for existence the England of to-day has had many advantages which must hide or neutralize the waste of war.

In default of facts unquestioned, we may appeal to the poets, letting their testimony as to the reversal of selection stand for what it is worth.

Rudyard Kipling is the poet of imperialism; and as to the cost of it all, we may well heed his testimony. This he says of the rule of the sea : -

We have fed our sea for a thousand years, And she calls us, still unfed;

Though there's never a wave of all her waves

But marks our English dead.

We've strawed our best to the waves' unrest,

To the shark and the sheering gull.

If blood be the price of Admiralty,

Lord God, we ha' paid it in full! 
There's never a flood goes shoreward now

But lifts some keel we have manned;

There's never an ebb. goes seaward now

But drops our dead on the sand,

But slinks our dead on the sands forlore,

From the Ducies to the Swin,

If blood be the price of Admiralty,

Lord God, we ha' paid it in!

We must feed our sea for a thousand years,

For that is our doom and pride,

As it was when they sailed with the Golden Hind

Or the wreck that struck last tide;

Or the wreck that lies on the spouting reef

When the ghastly blue-lights flare:

If blood be the price of Admiralty,

Lord God, we ha' bought it fair!

Again, referring to dominion on land, Kipling warns the British soldier:-

Walk wide o' the widow at Windsor,

For 'alf o' creation she owns:

We 'ave bought 'er the same with the sword an' the flame,

An' we've salted it down with our bones.

(Poor beggars! — it's blue with our bones!)

The

Human

Harvest

The

Widow at

Windsor

[89] 
The Human Harvest
The Revelry of the Dying

Older and more intense is " The Revelry of the Dying " of Bartholomew Dowling, - a bit of burning verse which was sung at the banquet of death in which Dowling himself was one of the first that died:- 
In the same vein is the dirge sung in Lee's Army in Virginia when General Pelham died:-

Oh, band in the pine-wood, cease!

Cease with your splendid call!

The living were brave and noble,

The dead were bravest of all!

They throng to the martial summons,

To the loud triumphant strain,

And the dear bright eyes of long-dead friends

Come to the heart again.

They come with the ringing bugle

And the deep drum's mellow roar,

Till the soul is faint with longing

For the hands we clasp no more!

$\mathrm{Oh}$, band in the pine-woods, cease!

Or the heart will melt in tears,

For the gallant eyes and the smiling lips

And the voices of old years!

Through all this we have the same refrain, the minor chord of victory, the hidden lesson of war.

I By John Esten Cooke. 


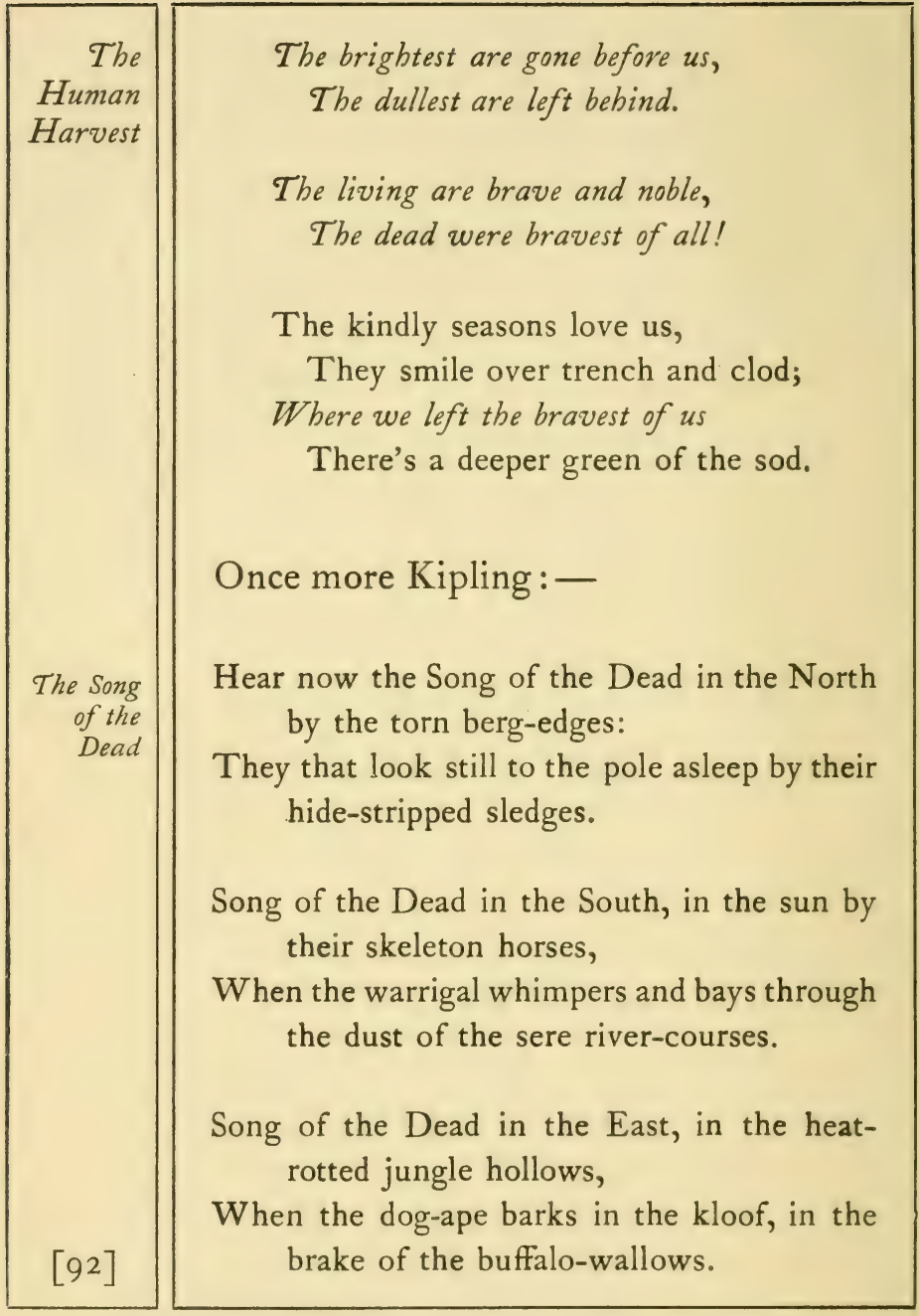


Song of the Dead in the West, in the barrens, the waste that betrayed them,

When the wolverene tumbles their packs from the camp and the grave-mound they made them.

And these lines of Mrs. Browning :-

Dead, one of them dead by the sea in the East,

And one of them dead in the West by the sea ;

Dead both of my boys, and ye sit at your feast, And you want a new song for your Italy free,-

Let none look at me!

In the stately "Ave Imperatrix" of Oscar Wilde there arevery noble lineswhich ought not to be forgotten, whatever our feeling toward the wretched life of their author:-

Set in this stormy northern sea,

Queen of these restless fields of tide,

England! what shall men say of thee,

Before whose feet the worlds divide?

The earth, a brittle globe of glass,

Lies in the hollow of thy hand,

And through its heart of crystal pass,

Like shadows through a twilight land,

The

Human

Harvest

Ave

Imperatrix 
The spears of crimson-suited war,

The long white-crested waves of light, And all the deadly fires which are

The torches of the lords of Night.

The yellow leopards, strained and lean,

The treacherous Russian knows so well, With gaping, blackened jaws are seen

Leap through the hail of screaming shell.

The strong sea-lion of 'England's wars

Hath left his sapphire cave of sea,

To battle with the storm that mars

The star of England's chivalry.

The brazen-throated clarion blows

Across the Pathan's reedy fen, And the high steeps of Indian snows

Shake to the tread of armèd men.

And many an Afghan chief, who lies

Beneath his cool pomegranate-trees,

Clutches his sword in fierce surmise

When on the mountain-side he sees

The fleet-footed Marri scout, who comes

To tell how he hath heard afar

The measured roll of English drums

Beat at the gates of Kandahar. 
For southern wind and east wind meet

Where, girt and crowned by sword and fire, England with bare and bloody feet

Climbs the steep road of wide empire.

O lonely Himalayan height,

Gray pillar of the Indian sky,

Where sawest thou in clanging fight

Our wingèd dogs of Victory?

The almond groves of Samarcand,

Bokhara, where red lilies blow; And Oxus, by whose yellow sand

The grave white-turbaned merchants go:

And on from thence to Ispahan,

The gilded garden of the sun, Whence the long dusty caravan

Brings cedar and vermilion;

And that dread city of Cabool,

Set at the mountain's scarpèd feet, Whose marble tanks are ever full

With water for the noonday heat;

Where through the narrow straight Bazaar

A little maid Circassian

Is led, a present from the Czar

Unto some old and bearded khan -

The

Human

Harvest 
Here have our wild war-eagles flown, And flapped wide wings in fiery fight;

But the sad dove, that sits alone

In England - she hath no delight.

In vain the laughing girl will lean

To greet her love with love-lit eyes;

Down in some treacherous black ravine,

Clutching his flag, the dead boy lies.

And many a moon and sun will see

The lingering wistful children wait

To climb upon their father's knee;

And in each house made desolate,

Pale women who have lost their lord

Will kiss the relics of the slain -

Some tarnished epaulet - some sword -

Poor toys to soothe such anguished pain.

For not in quiet English fields

Are these, our brothers, lain to rest,

Where we might deck their broken shields

With all the flowers the dead love best.

For some are by the Delhi walls,

And many in the Afghan land,

And many where the Ganges falls

Through seven mouths of shifting sand. 
And some in Russian waters lie,

And others in the seas which are

The portals to the East, or by

The wind-swept heights of Trafalgar.

O wandering graves! O restless sleep!

O silence of the sunless day!

O still ravine! O stormy deep!

Give up your prey! Give up your prey!

And thou whose wounds are never healed,

Whose weary race is never won,

$O$ Cromwell's England! must thou yield

For every inch of ground a son?

Go! crownwith thorns thy gold-crownedhead,

Change thy glad song to song of pain; Wind and wild wave have got thy dead,

And will not yield them back again.

Wave and wild wind and foreign shore

Possess the flower of English land -

Lips that thy lips shall kiss no more,

Hands that shall never clasp thy hand.

What profit now that we have bound

The whole round world with nets of gold,

If hidden in our heart is found

The care that groweth never old? 
The
Human

Harvest

What profit that our galleys ride,

Pine-forest-like, on every main?

Ruin and wreck are at our side,

Grim warders of the House of Pain.

Where are the brave, the strong, the fleet?

Where is our English chivalry?

Wild grasses are their burial-sheet,

And sobbing waves their threnody.

O loved ones lying far away,

What word of love can dead lips send!

$O$ wasted dust! O senseless clay!

Is this the end! is this the end!

Peace, peace! we wrong the noble dead

To vex their solemn slumber so:

Though childless, and with thorn-crowned head,

$U_{p}$ the steep road must England go.

Yet when this fiery web is spun,

Her watchmen shall decry from far

The young Republic like a sun

Rise from these crimson seas of war.

We have here the same motive, the same lesson, which Byron applies to Rome:-

The Niobe of Nations - there she stands, 
An empty urn within her withered hands,

Whose sacred dust was scattered long ago!

It suggests the inevitable end of all empire, of all dominion of man over man by force of arms. More than all who fall in battle or are wasted in the camps, the nation misses the "fair women and brave men" who should have been the descendants of the strong and the manly. If we may personify the spirit of the nation, it grieves most not over its " unreturning brave," but over those who might have been, but never were, and who, so long as history lasts, can never be.

Against this view is urged the statement that the soldier is not the best, but the worst, product of the blood of the English nation. Tommy Atkins comes from the streets, the wharves, the graduate of the London slums, and if the empire is "blue with his bones," it is, after all, to the gain of England that her better blood is saved for home consumption, and that, as matters are, the wars of England make no real drain of English blood.

Tommy Atkins 
The

Human

Harvest

In so far as this is true, of course the present argument fails. If war in England is a means of race improvement, the lesson I would read does not apply to her. If England's best do not fall on the field of battle, then we may not accuse war of their destruction. The fact could be shown by statistics. If the men who have fallen in England's wars, officers and soldiers, rank and file, are not on the whole fairly representative of "the flower of England's chivalry," then fame has been singularly given to deception. We have been told that the glories of Blenheim, Trafalgar, Waterloo, Majuba Hill, werewon by real Englishmen. And this, in fact, is the truth. In every nation of Europe the men chosen for the army are above the average of their fellows. The absolute best doubtless they are not, but still less are they the worst. Doubtless, too, physical excellence is more considered than moral or mental strength; and certainly, again, the more noble the cause, the more worthy the class of men who will risk their lives for it.

Not to confuse the point by modern in- 
stances, it is doubtless true that better men fell on both sides when "Kentish Sir Byng stood for the King" than when the British arms forced the opium trade on China. No doubt, in our own country better men fell at Bunker Hill or Gettysburg than at Cerro Gordo or Chapultepec. The lofty cause demands the lofty sacrifice.

It is the shame of England that most of her many wars in our day have cost her very little. They havebeenscrambles of the mob or with the mob, not triumphs of democracy.

There was once a time when the struggles of armies resulted in a survival of the fittest, when the race was indeed to the swift and the battle the strong. The invention of "villainous gunpowder" has changed all this. Except the kind of warfare called guerilla, the quality of the individual has ceased to be much of a factor. The clown can shoot down the hero, and, in the words of Charles F. Lummis, he "doesn't have to look the hero in the face while he shoots." The shell destroys the clown and hero alike, and the machine-gun mows down

The Survival of the fittest in war 
The whole ranks impartially. There is little play Human Harvest

What of America? for selection in modern war save what is shown in the process of enlistment.

America has grown strong with the strength of peace, the spirit of democracy. Her wars have been few. Were it not for the mob spirit, they would have been still fewer; but in most of them she could not choose but fight. Volunteer soldiers have swelled her armies, men who went forth of their own free will, knowing whither they were going, believing their acts to be right, and taking patiently whatever the fates might hold in store.

The feeling for the righteousness of the cause, "with the flavor of religion in it," says Charles Ferguson, "has made the volunteer the mighty soldier he has always been since the days of Naseby and Marston Moor." Only with volunteer soldiers can democracy go into war. When America fights with professional troops, she will be no longer America. We shall then be, with the rest of the militant world, under mob rule. "It is the mission of democracy," says Ferguson again, "to put down the rule of 
the mob. In monarchies and aristocracies it is the mob that rules. It is puerile to suppose that kingdoms are made by kings. The king could do nothing if the mob did not throw up its cap when the king rides by. The king is consented to by the mob because of that which in him is mob-like. The mob loves glory and prizes. So does the king. If he loved beauty and justice, the mob would shout for him while the fine words were sounding in the air; but he could never celebrate a jubilee or establish a dynasty. When the crowd gets ready to demand justice and beauty, it becomes a democracy, and has done with kings."

It was at Lexington that "the embattled farmers" "fired the shot heard round the world." To them life was of less value than a principle, the principle written by Cromwell on the statute-book of Parliament: "All just powers under God are derived from the consent of the people." Since the war of the Revolution many patriotic societies have arisen in the United States. These may be typified by the association of the "Sons of the Revolution," and of the

The

Human

Harvest

Significance of "Sons of the Revolution" 
The Human Harvest

"Sons of American Wars," societies which find their inspiration in the personal descent of their members from those who fought for American independence. The assumption, well justified by facts, is that revolutionary fathers were a superior type of men, and that to have had such names in our personal ancestry is of itself a cause for thinking more highly of ourselves. In our little private round of peaceful duties we feel that we might have wrought the deeds of Putnam and Allen, of Marion and Greene, of our Revolutionary ancestors, whoever they may have been. But if those who survived were nobler than the mass, so also were those who fell. If we go over the record of brave men and wise women whose fathers fought at Lexington, we must think also of the men and women who shall never be, whose right to exist was cut short at this same battle. It is a costly thing to kill off men, for in men alone and the sons of men can national greatness consist.

War sometimes inervitable War is sometimes inevitable. It is sometimes necessary, sometimes even righteous. 
It happened once in our history that for "every drop of blood drawn by the lash another must be drawn by the sword." It cost us six hundred and fifty thousand lives to get rid of slavery. And this number, almost a million, North and South, was the "best that the nation could bring." North and South, the nation was impoverished by the loss. The gaps they left are filled to all appearance. There are relatively few of us left to-day in whose hearts the scars of forty years ago are still unhealing. But a new generation has grown up of men and women born since the war. They have taken the nation's problems into their hands, but theirs are hands not so strong or so clean as though the men that are stood shoulder to shoulder with the men that might have been. The men that died in "the weary time" had better stuff in them than the father of the average man of to-day.

Those states which lost most of their strong young blood, as Virginia and South Carolina, will not recover forcenturies - perhaps never!

Read again Brownell's rhymed roll of hon-

The

Human

Harvest 


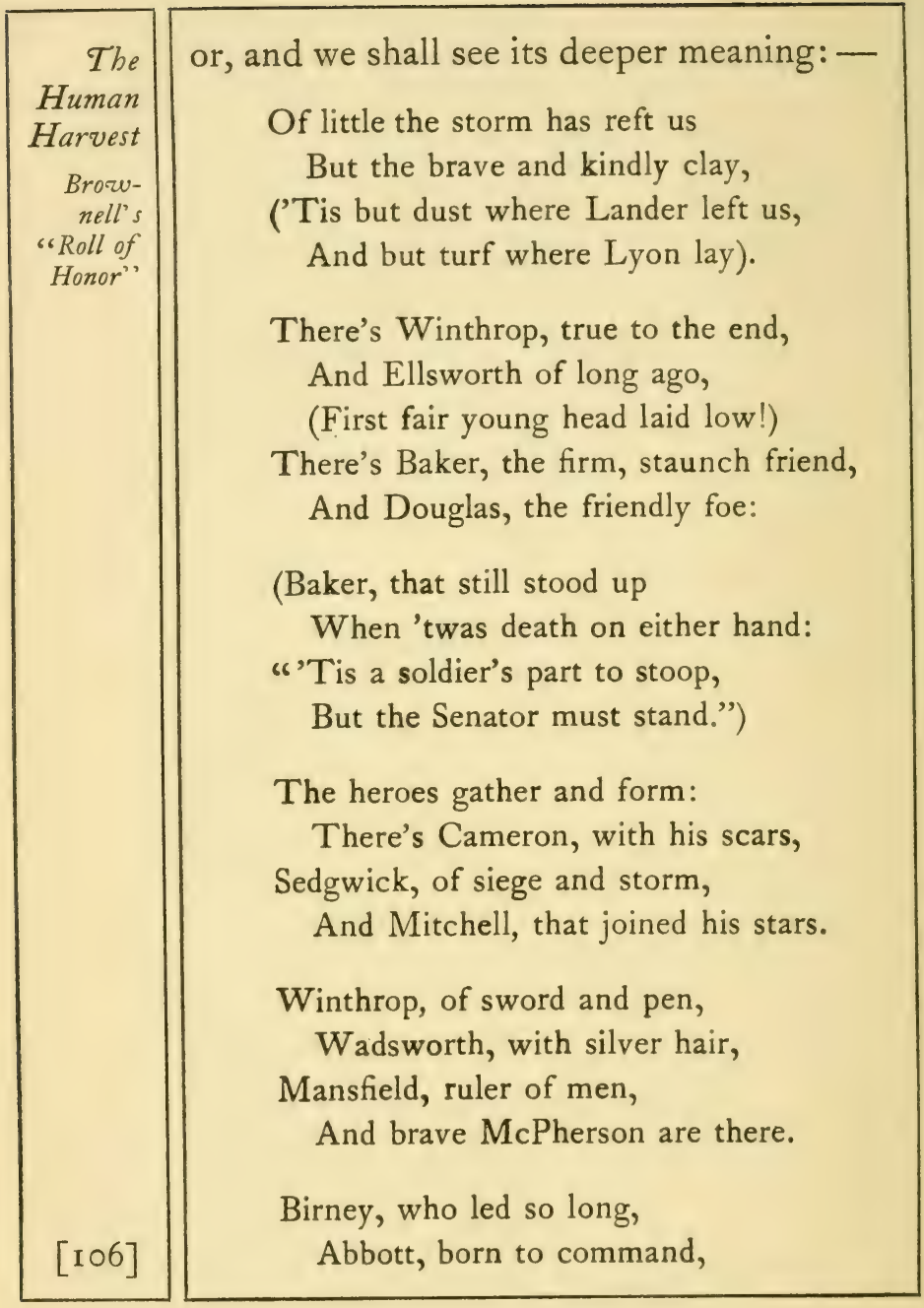


Elliott the bold, and Strong,

Who fell on the hard-fought strand.

Lytle, soldier and bard,

And the Ellets, sire and son, Ransom, all grandly scarred, And Redfield, no more on guard,

(But Alatoona is won!)

Reno, of pure desert,

Kearney, with heart of flame, And Russell, that hid his hurt

Till the final death-bolt came.

Terrill, dead where he fought, Wallace, that would not yield, And Sumner, who vainly sought A grave on the foughten field,

(But died ere the end he saw,

With years and battles outworn). There's Harmon of Kenesaw, And Ulric Dahlgren, and Shaw, ${ }^{I}$

That slept with his Hope Forlorn.

I Compare John Hay's reference to Colonel Shaw :With an eye like a Boston girl's;

And I saw the light of heaven that shone In Ulrich Dahlgren's curls ! 
Bayard, that knew not fear

(True as the knight of yore), And Putnam, and Paul Revere, Worthy the names they bore.

Allen, who died for others,

Bryan, of gentle fame, And the brave New-England brothers

That have left us Lowell's name.

Home, at last, from the wars, -

Stedman, the staunch and mild, And Janeway, our hero-child,

Home, with his fifteen scars!

There's Porter, ever in front, True son of a sea-king sire, And Christian Foote, and Dupont (Dupont, who led his ships Rounding the first Ellipse Of thunder and of fire).

There's Ward, with his brave death-wounds, And Cummings, of spotless name, And Smith, who hurtled his rounds When deck and hatch were aflame;

Wainwright, steadfast and true, Rodgers, of brave sea-blood, 
And Craven, with ship and crew

Sunk in the salt sea-flood.

And, a little later to part,

Our Captain, loved and dear-

(Did we deem thee, then, austere?

Drayton! - O pure and kindly heart!

Thine is the seaman's tear).

All such, - and many another

(Ah, list how long to name!)

That stood like brother by brother,

And died on the field of fame.

(But, a little from the rest,

With sad eyes looking down,

And brows of softened frown,

With stern arms on the chest,

Are two, standing abreast, -

Stonewall and Old John Brown).

But the stainless and the true,

These by their President stand,

To look on his last review,

Or march with the old command.

And lo, from a thousand fields,

From all the old battle-haunts,

A greater Army than Sherman wields,

A grander Review than Grant's!

The

Human

Harvest

[109] 


\begin{tabular}{|c|c|}
\hline $\begin{array}{r}\text { The } \\
\text { Human } \\
\text { Harvest }\end{array}$ & $\begin{array}{l}\text { Gathered home from the grave, } \\
\text { Risen from sun and rain, - } \\
\text { Rescued from wind and wave, } \\
\text { Out of the stormy main,- } \\
\text { The Legions of our Brave } \\
\text { Are all in their lines again! } \\
\text { Many a stout corps that went } \\
\text { Full-ranked from camp and tent, } \\
\text { And brought back a brigade; } \\
\text { Many a brave regiment, } \\
\text { That mustered only a squad. } \\
\text { The lost battalions } \\
\text { That, when the fight went wrong, } \\
\text { Stood and died at their guns, - } \\
\text { The stormers steady and strong. } \\
\text { With their best blood that bought } \\
\text { Scarp and ravelin and wall - } \\
\text { The companies that fought } \\
\text { Till a corporal's guard was all. } \\
\text { Many a valiant crew } \\
\text { That passed in battle wreck, } \\
\text { Ah, so faithful and true! } \\
\text { They died on the bloody deck, } \\
\text { They sank in the soundless blue. }\end{array}$ \\
\hline
\end{tabular}


The shattered wreck we hurried, In death-fight, from deck and port, The blacks that Wagner buried, That died in the Bloody Fort!

Comrades of camp and mess, Left, as they lay, to die, In the battle's sorest stress, When the storm of fight swept by: They lay in the Wilderness Ah, where did they not lie?

In the tangled swamp they lay, They lay so still on the sward! They rolled in the sick-bay, Moaning their lives away; They flushed in the fevered ward. But the old wounds are all healed, And the dungeoned limbs are free, The Blue Frocks rise from the field, The Blue Jackets out of the sea.

O tenderer green than May The Eternal Season wears, The blue of our summer's day

Is $\operatorname{dim}$ and pallid to theirs, The Horror faded away,

And 'twas heaven all unawares!' I "Abraham Lincoln," by Henry Howard Brownell.

The

Human

Harvest 


$$
\begin{array}{r}
\text { The } \\
\text { Haman } \\
\text { Thantom } \\
\text { Army }
\end{array} \mid \begin{aligned}
& \text { In the same vein Bret Harte tells us of } \\
& \text { the phantom "Last Review of the Grand } \\
& \text { Army of the Republic": - } \\
& \text { I saw a phantom army come } \\
& \text { With never a sound of fife or drum, } \\
& \text { But keeping time to a throbbing hum } \\
& \text { Of wailing and lamentation. } \\
& \text { The martyred heroes of Malvern Hill, } \\
& \text { Of Gettysburg and of Chancellorsville, } \\
& \text { The men whose wasted figures fill } \\
& \text { The patriot graves of the nation. } \\
& \text { And then came the nameless dead, the men } \\
& \text { Who perished in fever-swamp and fen, } \\
& \text { The slowly starved of the prison-pen; } \\
& \text { And, marching beside the others, } \\
& \text { Came the dusky martyrs of Pillow's fight, } \\
& \text { With limbs enfranchised and beaming bright ; } \\
& \text { I thought - but perhaps 'twas the pale moon- } \\
& \text { light - } \\
& \text { They looked as white as their brothers! } \\
& \text { And so all night marched the nation's dead, } \\
& \text { With never a banner above them spread, } \\
& \text { Nor a badge nor a motto brandishëd: } \\
& \text { No mark save the bare uncovered head } \\
& \text { Of the silent bronze Reviewer. }
\end{aligned}
$$


With never an arch save the vaulted sky, With never a flower save those that lie

On the distant graves - for love could buy No gift that was purer or truer.

" The remnant just eleven;

The bayonets one thousand were

And the swords were thirty-seven."

All the names that history has saved from the Civil War, as from any other war, are in the list of the officers. But no less worthy were the men in the ranks. It is the paradox of democracy that its greatness is less in the ranks. "Are all the common ones so grand, and all the titled ones so mean?" I North or South, it was the same. "Send forth the best ye breed" was the call on both sides alike, and to this call both sides alike responded. As it will take "centuries of peace and prosperity to make good the tall statures mowed down in the Napoleonic

IIs there never one in all the land, One on whose might the cause may lean? Are all the common ones so grand And all the titled ones so mean?',

- Edmund Clarence Stedman, i862.

The

Human

Harvest 
The

Human Harvest

wars," so like centuries of wisdom and virtue are needed to restore to our nation its lost inheritance of patriotism, - not the capacity for patriotic talk, for of that there has been no abatement, but of that faith and truth which "on war's red touchstone rang true metal." We can never know what might have been. We can never know how great is our actual loss, nor can we know how far the men that are fall short of the men that ought to have been.

\section{The gap in our picked and chosen,} The long years may not fill.

An English University professor on a late visit to America told me that his most vivid impression came from a casual reference to the one hundred and fifteenth (or some similarly numbered) regiment of Massachusetts volunteers - that a little district like Massachusetts should contribute I I 5,000 men to the Civil War gave an impression of the mightiness and the cost of that struggle he had gained in no other way.

It may be that the vexing problems of to[I I 4] day, the problems of greed and lawlessness, 
would be easier if we had the men who ought to havebeen to help us in their settlement. "The hencoop is always full, whatever the number of hens." Ourcountry fills up like an overflowing marsh ; but the men that are are not all of the same lineage with the men who might have been.

To some extent, at least, $V i r$ has given place to Homo in our American cities and in our public life. Among us, perchance, there might have been many a Brutus who would have brooked the Eternal Devil to take his seat in the Republic as easily as some of the tyrants to which we adjust ourselves in hopeless uncomplaint.

It is related that Guizot once asked this question of James Russell Lowell: "How long will the Republic endure?" "So long as the ideas of its founders remain dominant," was the answer. But again we have this question: "How long will the ideas of its founders remain dominant?" Just so long as the blood of the founders remains dominant in the blood of its people. Not necessarily the blood of the Puritans and the Virginians alone, the original creators of the land of

The

Human

Harvest

How long will the Republic last?

[ I $\left.\begin{array}{lll} & 5\end{array}\right]$ 
The free states. We must not read our history Human Harvest so narrowly as that. It is the blood of freeborn men, be they Greek, Roman, Frank, Saxon, Norman, Dane, Celt, Scot, Goth, or Samurai. It is a free stock which creates a free nation. Our republic shall endure so long as the human harvest is good, so long as the movement of history, the progress of science and industry leaves for the future not the worst but the best of each generation. The Republic of Rome lasted so long as there were Romans; the Republic of America will last so long as its people, in blood and in spirit, remain what we have learned to call Americans.

Like the seed is the harvest

[ $\left.\begin{array}{lll}1 & 1 & 6\end{array}\right]$ By the law of probabilities as developed by Quetelet, there will appear in each generation the same number of potential poets, artists, investigators, patriots, athletes and superior men of each degree.

But this law involves the theory of continuity of paternity, that in each generation a percentage practically equal of men of superior force or superior mentality should survive to take the responsibilities of parenthood. Otherwise Quetelet's law becomes 
subject to the operation of another law, the operation of reversed selection, or the biological "law of diminishing returns." In other words, breeding from an inferior stock is the sole agency in race degeneration, as selection natural or artificial along one line or another is the sole agency in race progress.

And all laws of probabilities and of averages are subject to a still higher law, the primal law of biology, which no cross-current of life can overrule or modify: Like the seed is the harvest.

Ruskin once said that "war is the foundation of all high virtues and faculties of men." As well might the maker of phrases say that fire is the builder of the forest, for only in the flame of destruction do we realize the warmth and strength that lie in the heart of oak. Another writer, Hardwick, declares that "war is essential to the life of a nation; war strengthens a nation morally, mentally and physically." Such statements as these set all history at defiance. War can only waste and corrupt. "All war is bad, some only worse than others." "War has

The

Human

Harvest

War as a source of national strength 
The

Human

Harvest

War one influence among many

\section{[I 118 8 ]}

its origin in the evil passions of men," and even when unavoidable or righteous its effects are most baleful. The final effect of each strife for empire has been the degradation or extinction of the nation which led in the struggle.

Itwill, no doubt, be said by those whoread this little book that all this is exaggeration, that war is but one influence among many, and that for each and all these forms of destructive selection civilization will find an antidote. This is very true. The antidote is found in the spirit of democracy, and the spirit of democracy is the spirit of peace. Doubtless these pages constitute an exaggeration. They were written for that purpose. I would show the "ugly, old, and wrinkled truth stripped clean of all the vesture that beguiles." Tosee anything clearly and separately is to exaggerate it. The naked truth is always a caricature unless clothed in conventions, fragments taken from lesser truths. The moral law is an exaggeration: "The soul that sinneth, it shall die." Doubtless one war will not ruin a nation. Doubtless it will not destroy its 
vitality or impair its blood. Doubtless a dozen wars may do all this. The difference is one of degree alone; I wish only to point out the tendency. That the death of the strong is a true cause of the decline of nations is a fact beyond cavil or question. The "man who is left" holds always the future in his grasp. One of the great books of our century will be some day written on the selection of men, the screening of human life through the actions of man and the operation of the institutions men have built up. It will be a survey of the stream of social history, its whirls and eddies, rapids and still waters, and the effect of each and all of its conditions on the heredity of men. The survival of the fit and the unfit in all degrees and conditions will be its subject-matter. This book will be written, not roughly and hastily, like the present fragmentary essay, the work of one whose business of life runs in wholly different lines. Still less will it be a brilliant effort of some analytical imagination. It will set down soberly and statistically the array of facts which as yet no one possesses; and the new Darwin whose work

The

Human

Harvest 
The

Human

Harvest

Advantages of civil war

it shall be must, like his predecessor, spend twenty-five years in the gathering of "all facts that can possibly bear on the question."

When such a book is written, we shall know for the first time the real significance of war. If any war is good, civil war must be best. The virtues of victory and the lessons of defeat would be kept within the nation. This would protect the nation from the temptation to fight for gold or trade. Civil war under proper limitations could remedy this. A time limit could be adopted, as in football, and every device known to the arena could be used to get the good of war and to escape its evils.

For example, of all our states, New York and Illinois have doubtless suffered most from the evils of peace, if peace has evils which disappear with war. They could be pitted against each other, while the other States looked on. The "dark and bloody ground" of Kentucky could be made the arena. This would not interfere with trade in Chicago, nor soil the streets of Baltimore. The armies could be filled up from the ranks of the unemployed, while the pasteboard 
heroes of the national guard could act as officers. All could be done in decency and order, with norecriminations and no oppression of an alien foe. We should have all that is good in war, its pomp and circumstance, the "grim resolution of the London clubs," without war's long train of murderous evils. Who could deny this? And yet who could defend it?

If war is good, we should have it regardless of its cost, regardless of its horrors, its sorrows, its anguish, havoc, and waste.

But war is bad, only to be justified as the last resort of "mangled, murdered liberty," a terrible agency to be evoked only when all other arts of self-defence shall fail. The remedy for most ills of men is not to be sought in "whirlwinds of rebellion that shake the world," but in peace and justice, equality among men, and the cultivation of those virtues we call Christian, because they havebeen virtues ever since man and society began, and will be virtues still when the era of strife is past, when false glory ceases to deceive, and when no longer

The

Human

Harvest

The best political economy

[I 2 I ] 


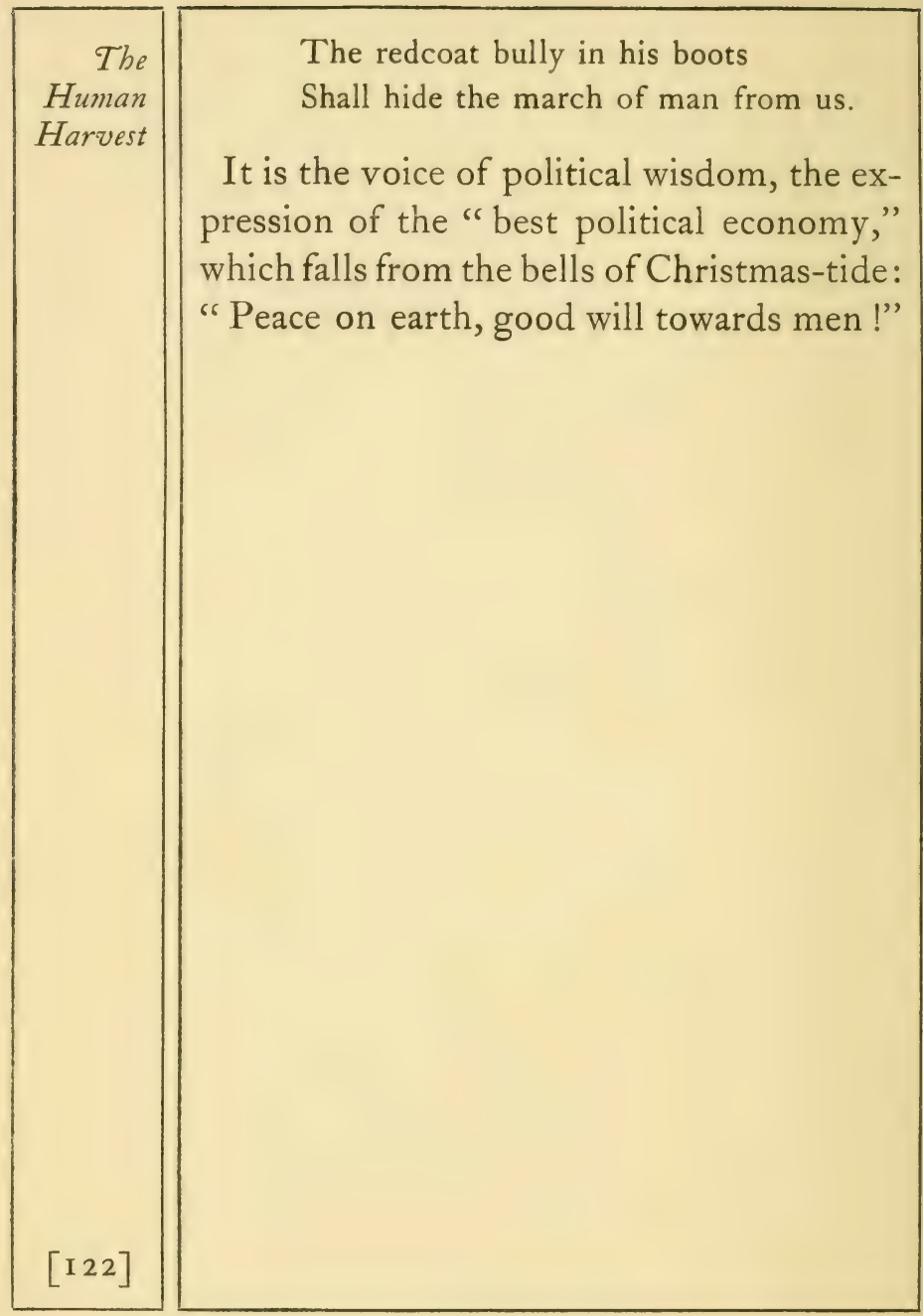









$$
11246
$$


